\title{
Changes in precipitation may alter food preference in an ecosystem engineer, the black land crab, Gecarcinus ruricola
}

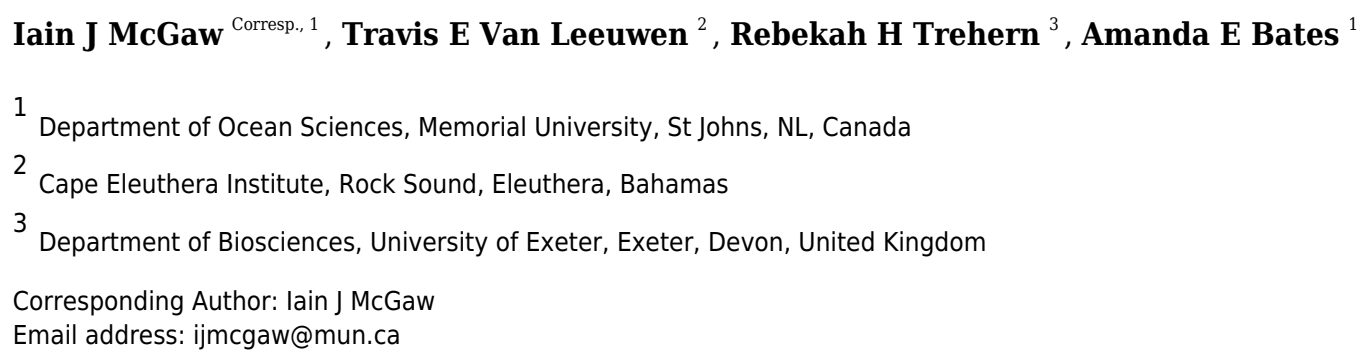

Gecarcinid land crabs are ecosystem engineers playing an important role in nutrient recycling and seedling propagation in coastal forests. Given a predicted future decline in precipitation for the Caribbean, the effects of dehydration on feeding preferences of the black land crab Gecarcinus ruricola were investigated. Gecarcinus ruricola were offered novel food items of lettuce, apple, or herring to test for food choice based on water and nutritional (energetic) content in single and multiple choice experimental designs. The effect of dehydration was incorporated by depriving crabs of water for 0,4 , or $8 d$, leading to an average body water loss of 0,9 and $17 \%$ respectively ( crabs survived a body water loss of $23+2 \%$ and 14-16 d without access to water). The results were consistent between the single and multiple choice experiments: crabs consumed relatively more apple and fish and only small amounts of lettuce. Overall, no selective preferences were observed as a function of dehydration, but crabs did consume less dry food when deprived of water and an overall lower food intake with increasing dehydration levels occurred. The decrease in feeding was likely due to loss of water from the gut resulting in the inability to produce ample digestive juices. Future climatic predictions suggest a $25 \%$ to $50 \%$ decline in rainfall in the Caribbean, which may lead to a lower food intake by the crabs, resulting in compromised growth. The subsequent reduction in nutrient recycling highlights possible long-term effects on coastal ecosystems and highlights the importance of future work on climate relative behavioural interactions that influence ecosystem function. 
1

3 Changes in precipitation may alter food preference in an ecosystem engineer, the black

4 land crab, Gecarcinus ruricola.

5

6

7

8 Iain J. McGaw ${ }^{1,2}$, Travis E. Van Leeuwen ${ }^{2}$, Rebekah H. Trehern ${ }^{2,3}$, Amanda E. Bates ${ }^{1}$

9 1. Department of Ocean Sciences, 0 Marine Lab Road, Memorial University, St John's, NL,

10 Canada A1C 5S7, Tel: 709-864 3272, Fax: 709 864-3220, email: ijmcgaw@mun.ca

11 2. Cape Eleuthera Institute, PO Box EL-26029, Rock Sound, Eleuthera, Bahamas

12 3. Department of Biosciences, University of Exeter, Prince of Wales Road, Exeter, Devon, EX4

13 4PS, United Kingdom

14

15

16 Running title: Dehydration alters feeding in land crabs

17

18

19

20

21

22

23

24

25

26

Peer] reviewing PDF | (2018:09:31035:2:0:NEW 8 Mar 2019) 


\section{Abstract}

29 Gecarcinid land crabs are ecosystem engineers playing an important role in nutrient recycling 30 and seedling propagation in coastal forests. Given a predicted future decline in precipitation for

31 the Caribbean, the effects of dehydration on feeding preferences of the black land crab

32 Gecarcinus ruricola were investigated. Gecarcinus ruricola were offered novel food items of

33 lettuce, apple, or herring to test for food choice based on water and nutritional (energetic) content

34 in single and multiple choice experimental designs. The effect of dehydration was incorporated

35 by depriving crabs of water for 0,4 , or $8 \mathrm{~d}$, leading to an average body water loss of 0,9 and

$3617 \%$ respectively (crabs survived a body water loss of $23 \pm 2 \%$ and $14-16 \mathrm{~d}$ without access to

37 water). The results were consistent between the single and multiple choice experiments: crabs

38 consumed relatively more apple and fish and only small amounts of lettuce. Overall, no selective

39 preferences were observed as a function of dehydration, but crabs did consume less dry food

40 when deprived of water and an overall lower food intake with increasing dehydration levels

41 occurred. The decrease in feeding was likely due to loss of water from the gut resulting in the

42 inability to produce ample digestive juices. Future climatic predictions suggest a $25 \%$ to $50 \%$

43 decline in rainfall in the Caribbean, which may lead to a lower food intake by the crabs, resulting

44 in compromised growth. The subsequent reduction in nutrient recycling highlights possible long-

45 term effects on coastal ecosystems and highlights the importance of future work on climate

46 relative behavioural interactions that influence ecosystem function. 


\section{Introduction}

Ecological research on climate change has largely focused on the influence of

environmental temperature as a driver for changes in biodiversity, nevertheless, global

precipitation regimes are also shifting with wet regions receiving increasingly more rainfall and drier regions becoming drier (Donat et al., 2016). Strong evidence suggests that desiccation can challenge water balance in terrestrial organisms, and thus set physiological constraints which in turn limit a species distribution (Terblanche \& Overgaard, 2015). By comparison, behavioural changes that allow species to adapt to the new climatic conditions have received less research effort than physiological mechanisms (Bellard et al., 2012). Thus behavioural flexibility is an additional mechanism that will not only influence species vulnerability to changing climate conditions, but also impact species that play key functional roles within ecosystems (Wong \&

63 Candolin, 2015).

The Caribbean region is one of the most vulnerable areas with respect to climate change

65 (Taylor et al., 2018). Not only is this region likely to experience gradual warming with average annual temperatures increasing by $0.6^{\circ} \mathrm{C}$ to $4^{\circ} \mathrm{C}$ by the end of the century (Campbell et al., 2011;

67 Taylor et al., 2018), more importantly this temperature change will be accompanied by a significant change in precipitation levels. At present the majority of rain in the Caribbean falls between May and October, with the dry season starting in November and peaking in February and March (Chen et al., 1997; Campbell et al., 2011). Although specific models vary between the

71 northern and southern Caribbean regions, most predict a drying scenario. Overall rainfall in the

72 Caribbean will decrease by approximately $25 \%$, but this could reach as high as $50 \%$ in some 
73 regions (Nurse \& Sem, 2001, Christensen et al., 2007; Campbell et al., 2011). Although

74 precipitation levels are predicted to decrease, this trend will not be consistent throughout the

75 entire year. The dry season is predicted to become somewhat wetter with an increase in major

76 rainfall days, whereas the number of dry days in the wet season will increase, especially during

77 the early part (May-July) of the season (Christensen et al., 2007, Campbell et al., 2011; Hall et

78 al., 2013; Taylor et al., 2011, 2013).

79 Brachyuran crabs of the family Gecarcinidae are large tropical and sub-tropical land

80 crabs and offer a compelling model taxon to investigate the impacts of changing precipitation

81 regimes because they are dependent on access to moisture. The crabs inhabit shaded forests and

82 scrub land where they construct burrows in soft earth or shelter among tree roots (Hartnoll et al.,

83 2006). Land crabs can be found many kilometers from the sea and at altitudes of up to $1000 \mathrm{~m}$

84 above sea level (Chace \& Hobbs, 1969; Britton et al., 1982; Jiminez et al., 1994). The family

85 Gecarcinidae contains six genera including crabs within the genus Gecarcinus which range in

86 distribution from subtropical areas of North and South America (Florida to Venezuela) and

87 throughout the Caribbean Islands. The genus Gecarcinus currently includes four species of which

88 the black land crab, Gecarcinus ruricola, is the most terrestrial of the Caribbean land crabs

89 (Taylor \& Davies, 1981). Although these crabs are classified as terrestrial they still have to

90 return to the sea to deposit their eggs. The larval stages develop at sea but return to land en masse

91 as megalopae after approximately one month (Hartnoll \& Clark, 2006).

92 A major obstacle associated with the movement onto land is water loss; while land crabs

93 are substantially less permeable than their aquatic counterparts, they do not approach the levels

94 of impermeability seen in true terrestrial arthropods. Therefore, water loss by evaporation,

95 primarily across the body surface and in the urine and feces, remains an important stressor 
96 (Herried, 1969; Wolcott, 1992). The ability to tolerate desiccation varies within the family

97 Gecarcinidae as a function of terrestriality. For example, Cardisoma species can tolerate between

98 15-20\% loss of body water (Gifford, 1962; Wood et al., 1986; Burggren \& McMahon, 1981;

99 Harris \& Kormanick, 1981), whereas Gecarcinus lateralis tolerates, on average, 21\% body water

100 loss, with some individuals losing over $30 \%$ of their body water before they succumb (Flemister,

101 1958; Bliss, 1968). Because of this high potential for water loss, land crabs must have

102 mechanisms to avoid desiccation; they can do this by constructing burrows, hiding in crevices, or

103 becoming semi-dormant and reducing metabolism during periods of drying (Wood et al., 1986;

104 Bliss et al., 1978; Wolcott, 1992). The crabs usually retreat to burrows in the winter when the

105 temperature drops below $15-18^{\circ} \mathrm{C}$, plugging the burrow and storing leaves as a food source. Not

106 only does temperature play a part in initiating this behaviour, it also helps them avoid water loss

107 during the dry winter period (Bliss et al., 1978). Unlike some of the less terrestrial crab species

108 (e.g. Cardisoma, Ocypode), crabs within the genus Gecarcinus usually do not have access to

109 moisture in the burrow, so they have to reduce their activity to conserve water. They usually only

110 emerge from their burrows after rains or when the humidity is high; this behaviour itself may

111 limit growth rates (Bliss et al., 1978).

112 Like most aquatic crabs, land crabs are classified as opportunistic omnivores because

113 their diet can include carrion, insects, animal feces and plant material (Fimpel, 1975; Bliss et al.,

114 1978; Wolcott \& Wolcott, 1984; Ortega-Rubio et al., 1997). However, the nature of their habitat

115 is such that they are primarily herbivorous, foraging on green leaves, herbaceous plants, flowers

116 and fleshy fruits, favoring these over dry leaf litter (Herreid, 1963; Wolcott \& Wolcott, 1984;

117 Kellman \& Delfosse, 1993; Greenaway \& Raghaven, 1998; Capistran-Barradas \& Moreno-

118 Casasola, 2006). This selective nature may be based on nutritional value, size and/or the 
119 chemical composition, for instance, Gecarcinus lateralis may avoid leaves with a high alkaloid

120 content (Capistran-Barradas \& Moreno-Casasola, 2006). Although land crabs can be selective,

121 access to high quality food is limited in many environments and subsequently they are often

122 forced to feed on a poor quality diet that is low in nitrogen and water content (Bliss et al., 1978,

123 Wolcott \& Wolcott, 1987; Linton \& Greenaway, 2007).

124 Gecarcinid crabs can reach remarkable densities in some areas and have been described

125 as ecosystem engineers because they are important in nutrient recycling, taking over the role of

126 earthworms (Sherman, 2002; Griffiths et al., 2007; Lindquist et al., 2009). They reduce the

127 amount of surface detritus and their burrowing activity aerates and turns-over the soil. The crabs

128 introduce nutrients deep into soil when they bring food down into the burrows and via the

129 subsequent production of faeces (Kellman \& Delfosse, 1993; Sherman, 2003, 2006). Land crabs

130 have also been found to feed selectively on seeds and seedlings which makes them key drivers of

131 tropical forest recruitment (Sherman, 2002; Lindquist et al., 2009). In addition the land crab

132 fishery is important throughout sub-tropical and tropical regions. Land crabs are a major source

133 of protein, economics and subsistence for many Caribbean Islanders (Baine et al., 2007);

134 however, they are susceptible to over harvest (Alayon, 2005; Baine et al., 2007). Given the

135 ecological and socio-economic importance and a future scenario of increased drying of the

136 habitat of Gecarcinus crabs the first aim of the study was determine the levels of water loss that

137 the black land crab, Gecarcinus ruricola, could tolerate as well as the basic metabolic changes

138 accompanying dehydration. Secondly we hypothesized that crabs of differing dehydration status

139 would exhibit selective feeding and choose different food items dependent on the water or

140 nutrient (energetic) content of the item being offered (Erickson et al., 2008; Nordhaus et al.,

141 2011). Finally, because these crabs play an essential role in nutrient recycling in coastal forests, 
142 we discuss how potential changes in feeding patterns could be important when predicting

143 responses to global environmental change for species which are strong community players and

144 influence ecosystem function.

145

146

147

148

149

150

151

152

154

\section{Methods and Materials}

\section{Crab collection and housing}

Eleuthera Island, The Bahamas is a largely undeveloped island. The limestone base is covered in a thin layer of sand/limestone particle soil which does not retain much water. The coastal forests consist largely of pine (Casuarina equisetifolia) close to the shoreline, which give way to scrub and mixed deciduous forest (Bahamas, National Trust). The majority of the rainfall on south Eleuthera falls between March and August, with a noticeable increase in the number of days without rain occurring between September and December (Ciabatta et al., 2017).

Intermoult adult male and female black land crabs, Gecarcinus ruricola, of 110-460 g were collected by hand at night, primarily from the mixed deciduous forest (February to May 2017). Crabs were transferred to the Cape Eleuthera Institute where they were housed in a slatted wooden hutch $170 \mathrm{~cm} \times 170 \mathrm{~cm} \times 170 \mathrm{~cm}$ with cardboard tubes providing a shelter for the crabs. The hutch was located under a shaded awning which maintained temperatures between $20-28^{\circ} \mathrm{C}$ and the animals were subjected to a natural day-night cycle. The crabs had free access to shallow plastic trays of fresh and salt water and were fed green leaves (mangrove species and sapodilla) ad lib. Animals were acclimated to these conditions for at least $7 \mathrm{~d}$ prior to being used in experiments. The animals were sexed and males and females randomly assigned to treatments. 
165 The treatment and care of the Gecarcinus ruricola complied with both Canadian and Bahamian

166 care protocols for crustaceans. All crabs used in the feeding preference experiments were

167 returned to the site of capture after use.

168

169

Responses to dehydration

170

In an initial series of experiments the crabs $(n=8)$ were deprived of water to determine the

maximal survivable water loss. They were not fed for the duration of the experiment to avoid

172 changes in mass associated with food consumption or production of metabolic water. The crabs

173 were held individually in covered perforated plastic boxes of $18 \mathrm{~cm} \mathrm{x} 12 \mathrm{~cm} \mathrm{x} 8 \mathrm{~cm}$ depth inside

174 the hutch with a diurnal temperature range of $20-28^{\circ} \mathrm{C}$ and a relative humidity $>80 \%$, these

175 conditions mimicked the burrow environment (Bliss, 1968). Crabs were weighed daily and water

176 loss was expressed as percentage loss of their initial body mass. The experiment was carried out

177 until each animal had become moribund and unresponsive to touch (these animals could be

178 revived by immersion in a tray of freshwater $(1 \mathrm{~cm}-2 \mathrm{~cm}$ depth) for $24 \mathrm{~h})$. The experiment was

179 then repeated in the experimental dehydration cages $(60 \mathrm{~cm} \mathrm{x} 60 \mathrm{~cm} \times 60 \mathrm{~cm})$ in the laboratory at

180 a temperature of $25^{\circ} \mathrm{C} \pm 2^{\circ} \mathrm{C}$. The crabs $(n=10)$, were weighed daily and the experiment was

181 terminated before they reached their lethal water loss level or noticeable changes in their

182 responsiveness to handling occurred. This approach allowed accurate determination of

183 experimental dehydration treatment periods that would physiologically stress, but not severely

184 incapacitate the crabs.

185 Oxygen consumption rates $\left(\mathrm{mg} \mathrm{O}_{2} \mathrm{~kg} \mathrm{~h}^{-1}\right)$ were measured to determine if dehydration had

186 any effect on the metabolic rate of the crabs. To measure oxygen consumption the crabs were

187 introduced into Lock and Lock ${ }^{\circledR}$ airtight plastic boxes (Anaheim, CA, USA) $24 \mathrm{~cm} \mathrm{x} 17 \mathrm{~cm}$ x 9 
$188 \mathrm{~cm}$ depth of $2.6 \mathrm{~L}$ volume and allowed to settle for $3 \mathrm{~h}$ after handling. All experiments were

189 performed during the daylight hours since land crabs become very active during the night

190 exhibiting a substantial increase in nocturnal heart rate (McGaw et al., 2018). Air temperature

191 within each plastic box was maintained at $27 \pm 1^{\circ} \mathrm{C}$. For readings the lids were sealed and the

192 boxes were covered in black plastic sheeting to avoid visual disturbance to the animals. The

193 boxes remained sealed for 45-70 minutes which allowed a measurable drop in oxygen without

194 exposing individuals to a hypoxic regime. A $60 \mathrm{ml}$ syringe with a 16 gauge needle was used to

195 collect an air sample. The needle was inserted through a small hole in the lid that was sealed with

196 dental wax. The syringe was pumped in and out three times to circulate the air in the chamber

197 before withdrawing an air sample. The sample was injected through a drierite ${ }^{\circledR}$ column (to

198 remove any moisture) into a Q-S102 $\mathrm{O}_{2}$ analyzer (Qubit Systems, Ontario, Canada). The oxygen

199 analyzer was pre-calibrated with room air as $100 \%$ oxygen saturation $(20.95 \%$ oxygen $)$, and

200 nitrogen gas was used for $0 \%$ saturation. The chamber was opened between readings to allow

201 fresh air to circulate. Aerial oxygen consumption $\left(\mathrm{ml} \mathrm{kg} \mathrm{h}^{-1}\right)$ was calculated taking into account

202 the volume of the chamber minus the volume of air displaced by the crab in the chamber, the

203 mass of the crab and the length of time the chamber remained closed. This value was converted

204 from milliliters $\mathrm{h}^{-1}$ to milligrams $\mathrm{h}^{-1}$ by multiplying by $1.43\left(32 \mathrm{~g} \cdot \mathrm{mol}^{-1}\right.$ divided by $\left.22.4 \mathrm{l} \cdot \mathrm{mol}^{-1}\right)$.

205 The oxygen consumption of crabs was monitored during an $8 \mathrm{~d}$ dehydration period, this

206 was based upon the water loss and survival experiments (described above). The crabs (n=8) had

207 been starved for $2 \mathrm{~d}$ prior to the initial reading ( $0 \mathrm{~d}$ dehydration) because feeding and digestion is

208 associated with an increased metabolic rate termed the specific dynamic action (McGaw, 2005;

209 Secor, 2009). Readings were taken at 0, 2, 4, 6 and $8 \mathrm{~d}$ of dehydration during which time the

210 crabs were not fed. Following this $8 \mathrm{~d}$ dehydration period the crabs were allowed to rehydrate 
211 and oxygen consumption was measured after a $24 \mathrm{~h}$ recovery period. A second group of crabs

$212(\mathrm{n}=8)$ was also monitored under the same time regime, however, this group was given free access

213 to water. This enabled us to determine if changes in oxygen consumption were associated with

214 dehydration as opposed to food deprivation (Ansell, 1973).

215 The metabolic scope of dehydrated crabs $(n=8)$ was also calculated using separate

216 animals (from above) that were deprived of water for $0 \mathrm{~d}, 4 \mathrm{~d}$, or $8 \mathrm{~d}$. The crabs were placed in

217 the chambers and allowed to settle for $3 \mathrm{~h}$ before a reading was taken; this was the resting

218 metabolic rate (RMR). The crabs were then removed from the chamber and forced to walk for

219 approximately five min by constantly agitating them with a stick. A thick elastic band was then

220 wrapped around each side of the carapace and a metal weight was inserted into the bands on the

221 upper surface of the carapace after which the crabs were placed back into the chamber in an

222 inverted position which caused them to struggle vigorously trying to right themselves. This

223 forced activity and subsequent struggling behaviour produced the maximal metabolic rate

224 (MMR) (McGaw, 2007). The difference between the RMR and MMR was calculated as the 225 metabolic scope.

Food preferences

Prior to experimentation the crabs were transferred to wire mesh cages $(60 \mathrm{~cm} \mathrm{x} 60 \mathrm{~cm} \mathrm{x}$

$60 \mathrm{~cm}$ and $2.5 \mathrm{~cm}$ mesh) in the laboratory and deprived of water for 0,4 or $8 \mathrm{~d}$. This represented a water loss of approximately 0,9 and $17 \%$ of the body mass respectively. The feeding regime

231 was also controlled during this time so at the time of experimentation the crabs had been fasted

232 for $8 \mathrm{~d}$ for each dehydration level. A fasting period of $8 \mathrm{~d}$ was selected because crabs produced 
233 faeces for up to $6 \mathrm{~d}$ after consuming large meals (pers. obs.); this period also ensured the

234 stomach was empty and they would feed when offered food (Mchenga \& Tsuchiya, 2010).

235 To determine food preferences individual crabs were held in covered opaque plastic

236 containers $\left(30 \mathrm{~cm} \times 30 \mathrm{~cm} \times 60 \mathrm{~cm}\right.$ depth) in the laboratory at a temperature of $25^{\circ} \mathrm{C} \pm 2^{\circ} \mathrm{C}$. The

237 crabs were allowed to settle in the containers for $1 \mathrm{~h}$ after handling before weighed portions of

238 the food were introduced. As land crabs exhibit nocturnal foraging behavior (Palmer, 1971) the

239 food was placed in the containers in the evening (approximately $8 \mathrm{pm}$ ) and they were left to feed

240 for $12 \mathrm{~h}$; all experiments were carried out in constant darkness. In the morning food was weighed

241 for post-consumption mass. Three different types of food were offered - lettuce leaves (water

242 content $=93.83 \pm 0.27 \%$, energetic content $=59 \mathrm{~kJ} / 100 \mathrm{~g})$, apple slices (water content $=85.57 \pm$

$2430.56 \%$, energetic content $=218 \mathrm{~kJ} / 100 \mathrm{~g}$ ), and herring (fish) fillets (water content $=64.88 \pm$

$2440.62 \%$, energetic content $=661 \mathrm{~kJ} / 100 \mathrm{~g}$ ). These items were chosen as novel items that the crabs

245 would not normally encounter to try and ensure the crabs would make a choice based upon water

246 or nutrient (energetic) content of the food. While naturally occurring plants could have been used

247 they did not exhibit pronounced differences in nutrient and water content - more importantly if

248 preference did occur we would be unable to determine if this was affected by familiarity with, or

249 preference for, that naturally occurring item (Thacker, 1996, 1998).

250 In the first series of experiments the crabs ( $\mathrm{n}=14$ per food type, and $120 \mathrm{~g}$ to $405 \mathrm{~g}$ range)

251 were offered just one food item - fresh (unaltered, raw) lettuce, fresh apple, fresh fish, or dry

252 lettuce, dry apple, or dry fish (that had been dried to constant weight in a drying oven at $60^{\circ} \mathrm{C}$ ).

253 Fourteen animals (one crab per container) were run at any one time with food types and

254 dehydration levels randomly assigned. This enabled us to determine differences in palatability

255 and feeding rates on each of the foods (Peterson \& Renaud, 1989). Because offering single items 
256 are not true preference experiments a second experiment was carried out and the crabs were

257 offered a multiple choice of the food items (Peterson \& Renaud, 1989; Bergamino \& Richoux,

258 2015). The results of the first series of experiments suggested that the crabs did not eat the dried

259 items as readily as the fresh items. Therefore only the three fresh foods were given to the crabs

260 and they were allowed to feed for $12 \mathrm{~h}$ in constant darkness. The three food types were

261 introduced at the same time and an excess of each type was added to ensure the crabs did not

262 consume all of one type and then start feeding on the next type simply because they had

263 consumed all the preferred food items.

264 In a final series of experiments a wider size range of crabs (26 g to $475 \mathrm{~g}$ ) was used to

265 determine if there was any food preference based upon the size of and/or sex animal. For this

266 experiment only fully hydrated crabs were used and they were only offered the multiple choice

267 of three fresh foods.

268

269

\section{Calibration of amount eaten}

270

To control for weight changes of both the fresh and dry food, samples of different shape

271 and mass ( $\mathrm{n}=22$ to 38$)$ were placed in containers without crabs and weighed again after $12 \mathrm{~h}$.

272 Regression lines were produced for each food type (Table 1) and correction factors were applied

273 to calculate the final mass eaten. Because of the different water content of the three food types

274 and differences in water content between the fresh and dry foods (Table 1), the mass eaten was

275 converted to a dry mass for all food types. Samples of fresh food ( $\mathrm{n}=18$ to 24$)$ were weighed and

276 dried to constant mass in a drying oven at $60^{\circ} \mathrm{C}$, regression equations used to convert the fresh

277 mass eaten into dry mass eaten (Table 1). The crabs varied in size (carapace width) and even

278 crabs of a similar size varied in mass because of their dehydration status. Therefore in order to 
279 standardize for crab size and wet body mass, the dry body mass of the crab was used. Hydrated

280 crabs $(\mathrm{n}=18)$ varying between $90 \mathrm{~g}$ and $450 \mathrm{~g}$ were weighed and then euthanized by being placed

281 in iced water for $1 \mathrm{~h}$. The crabs were then dried to constant mass in an oven (Table 1). The

282 amount of food eaten was expressed as a dry mass as a percentage of the dry body mass of an

283 individual crab (Steinke et al., 1993).

284

285 Statistical analysis

286 Cumulative days without rainfall were calculated using the global scale rainfall product,

287 SM2RAIN-CCI (Ciabatta et al., 2017). Rainfall data for the $0.25^{\circ}$ grid cell encompassing the

288 Cape Eleuthera Institute ( $\left.24^{\circ} 49^{\prime} 45^{\prime \prime} \mathrm{N}, 7^{\circ} 19^{\prime} 46^{\prime \prime} \mathrm{W}\right)$ was extracted for the time span from

$2891998 / 01 / 01$ to 2015/12/31 and quantified cumulative daily rainfall. For each month of each year

290 the total number of consecutive days without rainfall were calculated and the maximum span of

291 days without rainfall for each month was used as the response of interest. This allowed us to

292 calculate historical mean number of days without rainfall, and compare this to chosen times for

293 dehydration $(0,4,8 \mathrm{~d})$ used in experiments.

294 Differences between oxygen consumption rates of hydrated and dehydrated crabs as a

295 function of time were tested for using two-way repeated measures ANOVA. Data showing

296 significant effects were further analyzed using Tukey post-hoc tests. Differences in maximal

297 metabolic rate and scope were tested for with a one-way repeated measures ANOVA, followed

298 by Tukey post-hoc tests to determine where significant differences occurred.

299 We tested for a preference for certain types of food when the crabs were offered a) single

300 food items of fresh or dry food and b) a multiple choice of 3 types of fresh food, and if c) crab

301 size (juvenile to adult) had an effect on food selection. For the single food offerings and 
302 multiple-choice experiments, the percent body mass food consumed fit the assumptions of a

303 Poisson distribution, and the data was multiplied by 100 and rounded for input into general linear

304 regression models. Body size and sex were included as covariates, but these variables were

305 excluded in model reduction because their inclusion did not reduce the model AIC score (Akaike

306 Information Criterion).

307 We used a (glm, function glm in the base stats package in R; Team 2017) to test for

308 difference in the quantities of food for crabs offered a single choice. In the multiple-choice

309 experiment crab identification number was initially included as a random effect to account for

310 repeated measures on the same individuals (each crab potentially feeding on the 3 different food

311 items), using the function glmmPQL in the package MASS (Venables and Ripley 2002). The

312 random effect of crab identity was not retained because it explained $<0.001 \%$ of the model

313 variance and inclusion of this parameter did not improve the model fit based on AIC. Thus, we

314 used a glm. To test for food consumption in relation to body mass a generalized least squares

315 regression model using the function gls in the package nlme was performed (Pinheiro et al.

316 2017). This allowed us to model the unequal variance structure in the different food treatments

317 (lettuce, apple and fish) using the weights parameter and varIdent.

318 Model results summary tables report the coefficients for each factor, based on p-values

319 and whether the $95 \%$ confidence intervals cross zero. Coefficients represent treatment contrasts

320 of food types apple and fish versus lettuce, moisture level (dry versus fresh food), and days of

321 dehydration exposure 4 and 8 , versus 0 . The coefficients were used to calculate the $\%$ difference

322 in food consumed using the function predict. In each model, fresh lettuce at $0 \mathrm{~d}$ dehydration was

323 used as the reference with which to compare the other food and dehydration treatments, because

324 fresh lettuce is similar to naturally occurring food items (leaves) of Gecarcinus species (Bliss et 
325 al, 1968; Wolcott and Wolcott, 1984). Moreover, preliminary experiments using $0 \mathrm{~d}$ dehydrated

326 crabs $(\mathrm{n}=10)$ fed green sapodilla leaves indicated no significant difference in the amount of fresh

327 lettuce and green sapodilla leaves consumed by the crabs (Wilcoxon rank sum test with

328 continuity correction; $\mathrm{W}=28, \mathrm{p}$-value $=0.306$ ). This result was supported by a generalized linear

329 model (glm) with crab size as a covariate (results not presented).

\section{Results}

341 Field Observations

342 On Eleuthera Island, Gecarcinus ruricola, was primarily found in the deciduous forest 343 and scrubland, and was less common in the pine forest closer to the shore. The available food

344 items in the deciduous forest and scrubland were primarily fallen dry leaves, herbaceous plants

345 and grasses. The crabs were nocturnal, starting to emerge at dusk, retreating to shelter before

346 sunrise. Crabs were only occasionally seen on the surface during the months of December

347 through February but could be collected by excavating burrows or lifting rocks and logs. The 
348 animals started to appear on the surface during March and April and were found in large

349 numbers, especially after rains, from mid-April onwards. Numerous small burrows were found in

350 the scrubland and under the forest canopy. When we excavated the burrows most were between

35130 and $45 \mathrm{~cm}$ in length and housed a single small crab $(<80 \mathrm{~g})$. The surface soil as well as that at

352 the base of the burrow did not retain any moisture and the dry soil could be easily crumbled

353 between the fingers. Larger burrow entrances were less common and we tended to find larger

354 crabs $(>200 \mathrm{~g})$ under rocks and logs, in limestone crevices, or in depressions covered by leaf

355 litter. Due to the porous nature of the soil and bedrock, permanent bodies of standing freshwater

356 were rare. Dew did form overnight during the cooler months (November to April), however, this

357 was less consistent during the remainder of the year, and dews was only evident in open areas on

358 grasses and low lying shrubs. Small pools of standing water persisted for 1 to $2 \mathrm{~d}$ following

359 heavy rainfall. After such events the crabs emerged from the forest en masse (approximately 2 to

3607 crabs per $\mathrm{m}^{2}$ ) and were out in the open during the daylight hours. The crabs gathered in large

361 numbers around these pools to drink water (Fig. 1).

362

363

364 Precipitation levels and responses of crabs to dehydration

365 The consecutive number of days without rain for each month was plotted for the period

3661998 to 2015 (Fig. 2). There was considerable variation from year to year, however during the

367 month of June, in 4 out of the 18 years, rain fell every day. In contrast, during the months of

368 September through December there were times (between 1 and 4 years) when rain did not fall

369 during the entire month. In general the number of days without rainfall (median levels of 9 to 12

370 d) in the months of September to January were similar to one another, but higher than the 
371 number of days without rainfall between February to August (median levels of 3 to $7 \mathrm{~d}$ ), which

372 were similar to one another (one-way ANOVA, $\mathrm{df}=11, \mathrm{~F}=7.02, \mathrm{P}<0.001$ ).

373 In the water loss experiments the crabs exhibited a relatively constant daily water loss of

374 between 1.4 and $2 \%$ of their body weight (Fig. 3). The animals became moribund and

375 unresponsive to touch between $14 \mathrm{~d}$ and $16 \mathrm{~d}$; the mean estimated "lethal" level was $23.7 \pm 2.9 \%$

376 body water loss. In the open cages in the lab the rate of water loss was slightly faster (Fig. 3).

377 The animals were maintained for $9 \mathrm{~d}$ at which time mean water loss was $19.2 \%$. We thus

378 selected dehydration periods of $4 \mathrm{~d}$ and $9.2 \% \pm 0.4 \%$ and $8 \mathrm{~d}$ and $17.3 \% \pm 1.1 \%$ water loss, a

379 regime which ensured that the crabs were not so severely incapacitated that they could not feed

380 or function properly.

381 The oxygen consumption rates were somewhat variable for both dehydrated and hydrated 382 crabs (Fig. 4). There was a significant decline in oxygen consumption of the dehydrated crabs at

$3838 \mathrm{~d}$ (Two-Way RM ANOVA, $\mathrm{df}=1,5$, Interaction, $\mathrm{F}=2.96, \mathrm{P}=0.018$ ), whereas oxygen

384 consumption rates for hydrated crabs remained unchanged during the $8 \mathrm{~d}$ treatment and the

385 recovery period. Pre-treatment oxygen consumption rates were regained in the dehydrated crabs

386 within $24 \mathrm{~h}$ of rehydration. The maximal metabolic rate of dehydrated crabs (MMR) ranged

387 between mean values of $139 \pm 13$ and $199 \pm 18 \mathrm{mg} \mathrm{O}_{2} \mathrm{~kg} \mathrm{~h}^{-1}$ (Table 2). There was a slight, but

388 significant difference among these values (one-Way RM ANOVA, $\mathrm{df}=3, \mathrm{~F}=2.9, \mathrm{P}=0.048$ ). This

389 occurred because oxygen consumption rates at $4 \mathrm{~d}$ were higher than those measured at $8 \mathrm{~d}$ and

390 during the recovery period. The metabolic scope varied between 2.4 and 4.6 (Table 2). The

391 metabolic scope of 4.6 measured after 8 d dehydration was significantly higher than that

392 measured at $0 \mathrm{~d}$ and after the $24 \mathrm{~h}$ recovery period (one-way RM ANOVA on ranks, $\mathrm{df}=3$,

$393 \mathrm{H}=18.22, \mathrm{P}<0.001)$. 
395 Feeding preferences

396 When offered single items of fresh or dry lettuce, apple, or fish there was a strong effect

397 of moisture content of the food with animals eating anywhere from 3 to 6 times more fresh food

398 than dry food (GLM, df=238, $t=-33.34, p, 0.001$; Fig. 5, Table 3). This is because nearly all the

399 animals fed on the fresh food, but less crabs overall fed on the dry food, and the proportion of

400 crabs feeding on the dry food declined with increasing dehydration levels (Table 4). In particular

401 for the dry treatment, there was a significant overall effect of dehydration on feeding; crabs ate

402 less lettuce at both 4 and $8 \mathrm{~d}$, compared to $0 \mathrm{~d}(\mathrm{GLM}, \mathrm{df}=238, \mathrm{t}=-16.66$ and $-20.99, \mathrm{P}<0.001$; Fig

403 5, Table 3). The crabs ate most apple, followed by fish, and consumed significantly less lettuce.

404 In the dry treatment the amount of each food type consumed was not affected by the moisture

405 content of the food, or the number of days the animals had been dehydrated (Fig. 5). However,

406 crabs did consume more fish at $4 \mathrm{~d}$ dehydration in the fresh treatment (GLM, $\mathrm{df}=238, \mathrm{t}=26.96$, $407 \mathrm{p}, 0.001)$

408 In contrast to the single food type experiments when crabs were offered multiple fresh

409 food items, fish was consumed in higher amounts compared to apple, followed by lettuce, of

410 which only small amounts $(<8 \%$ of all food) were consumed (Fig. 6 , Table 5 - see coefficients

411 for the day * food type interactions). There was also an interactive effect of dehydration; for

412 lettuce only very low amounts were consumed and there was no effect of dehydration on the

413 amount consumed (GLMM, $\mathrm{df}=117, \mathrm{t}=-1.01$ and $0.96, \mathrm{p}=0.32$ and 0.34$)$. The crabs ate less apple

414 at $4 \mathrm{~d}$, compared to $0 \mathrm{~d}$, and the amount consumed dropped further at $8 \mathrm{~d}$ (GLMM, df=117, $4 \mathrm{~d}$

$415 \mathrm{t}=-7.95, \mathrm{p}<0.001 ; 8 \mathrm{~d}, \mathrm{t}=-11.82, \mathrm{p}<0.001)$. For fish a significant effect of dehydration was only

416 evident at $8 \mathrm{~d}(\mathrm{GLMM}, \mathrm{df}=117, \mathrm{t}=-3.60, \mathrm{p}<0.001)$, here the $1.6 \pm 0.04 \%$ body weight $(\mathrm{BW})$ 
417 consumed was lower than that measured at $0 \mathrm{~d}(2.1 \% \pm 0.04 \% \mathrm{BW})$ and $4 \mathrm{~d} .(2.4 \pm 0.04 \% \mathrm{BW})$.

418 These differences were underpinned by the number of animals feeding (Table 6); most of the

419 crabs (between 10 and 13) ate some apple and fish when given a choice of all 3 food items, while

420 only 5 to 11 individuals fed on the lettuce (Table 6).

421 When a wider range of crab sizes encompassing juveniles (25g) to adults (480g) were

422 included, diet preferences of crabs were found to be size dependent (Generalized least squares

423 regression, $\mathrm{df}=162, \mathrm{t}=-5.60, \mathrm{p}<0.001$; Fig. 7, Table 7). As in the other experiments, regardless of

424 crab size apple and fish were preferred over lettuce. However, smaller crabs ate slightly more

425 lettuce than the larger animals. In addition the smaller crabs ate almost twice as much fish as the

426 largest crabs and the amount of fish consumed declined as the crab mass increased. In contrast

427 the largest crabs ate twice as much apple compared with the smallest crabs and the amount of

428 apple consumed increased with increasing crab size (Fig. 7; Table 7; Generalized least squares

429 regression, $\mathrm{df}=162, \mathrm{t}=2.63, \mathrm{p}=0.01)$.

430

431

432

433

434

435

436

437

438 Discussion 
440 decrease in all food items, but especially dry matter, with increasing dehydration status. Given

441 the future predictions of drier climate for the Caribbean, the corresponding dehydration in this

442 species will influence its ability to fulfill its role as an ecosystem engineer in coastal forest 443 ecosystems.

Precipitation levels and responses to dehydration

A decrease in Caribbean rainfall levels of between $25 \%$ and $50 \%$ is forecast by the end of the century (Nurse and Sem, 2001, Christensen et al 2007; Campbell et al 201). Given the potential loss of standing water and associated lower humidity this would increase the number of days that the crabs would be at a higher risk of dehydration stress and thus alter foraging patterns. Moreover the timing of the dry season is important, which in the Caribbean lasts from November through to April (Chen et al., 1997; Campbell et al., 2011). However, the rainfall data from south Eleuthera, Bahamas showed the greatest number of consecutive days without rain between September and January. Given this scenario it could lead to an increase in the mean number of dry days during September to January from $13.5 \mathrm{~d}$ to between 16.9 (25\% increase) and $20.3 \mathrm{~d}$ (50\% increase), a significant finding given that the crabs in our study became moribund after only 14 days under the predicted future climatic regime. The temperatures during the first part of this dry season are still high and the crabs would be active and foraging, rather than hibernating in burrows (Bliss et al., 1966, 1978) and so they would be directly affected.

459 Although the crabs may have be able to obtain some of their water needs through metabolic 460 water or drinking dew (Wolcott \& Wolcott, 1988), this was clearly insufficient. The fact that the 461 crabs emerged during the daylight hours, and risked predation (Ortega-Rubio et al., 1997) to 
462 drink from temporary pools indicate that precipitation events are essential in order to balance

463 their water budget.

464 G. ruricola could withstand $23 \pm 2 \%$ body water loss, which is similar to the $21-22 \%$

465 water loss reported for the closely related species G. lateralis (Bliss et al., 1966) and within the

466 range of other land crabs (Herried, 1969; Wood et al., 1986). Fatal body water loss occurred

467 within 14-16 d without access to water. During this time the crabs were not fed; one would

468 assume that metabolic water from food would be very important (Wolcott \& Wolcott, 1987;

469 Wolcott, 1992), and although $23 \%$ body water loss would likely be fatal, the time to reach this

470 level would typically be longer than 14-16 d. It could also be argued that the crabs would retreat

471 into the burrow where the air is usually fully saturated, and that this would slow water loss (Bliss

472 et al., 1978). However, G. ruricola is not always able to construct or inhabit burrows and the

473 larger animals in particular are often found in crevices or under rocks where they would be more

474 prone to dehydration (Wolcott, 1992; Griffiths et al., 2007; present study observations). That

475 being said, given the use of metabolic water and changes in behaviour, even the most extreme

476 predicted climatic changes would probably not prove fatal for this species. Nevertheless, an

477 increase in dehydration levels coupled with changes in feeding patterns will likely lead to

478 reduction growth and overall physiological condition in these crabs (Bliss et al, 1978; Wolcott

479 and Wolcott, 1984).

480 Oxygen consumption rates of water deprived G. ruricola remained unchanged until $8 \mathrm{~d}$ of

481 dehydration; because the hydrated animals did not show the same decline in oxygen

482 consumption, the decline in oxygen consumption in crabs without access to water was associated

483 with dehydration rather than simply being a result of food deprivation for $8 \mathrm{~d}$ (Ansell, 1973;

484 Wallace, 1973). In contrast to the responses observed for G. ruricola, oxygen consumption in 
485 Cardisoma guanhumi declines within 36 h without water (Wood et al., 1986) and even slight

486 water loss $(<4 \%)$ in Ocypode quadrata causes a decrease in $\mathrm{VO}_{2 \mathrm{Max}}$ (Weinstein et al., 1994).

487 Both of these species are less terrestrial in habitat than G. ruricola and its responses showed it is

488 better able to tolerate desiccation (Taylor \& Davies, 1981). During experiments G. ruricola were

489 active and could be heard moving around in the covered plastic containers, but the dehydrated

490 animals were noticeably less active at day 8 . This behavioural suppression in activity as a

491 function of dehydration has also been reported for another species, Holthuisana quadratus

492 (Greenaway et al., 1983). The fact that the maximal metabolic rates of G. ruricola were

493 unaltered after $8 \mathrm{~d}$ dehydration (Table 2) also suggests that it was a behavioural reduction in

494 activity, rather than a physiologically regulated mechanism. Dehydrated crabs can gain a lot

495 water within a few hours, with pre-treatment levels regained after $24 \mathrm{~h}$ (Bliss et al., 1966; Wood

496 et al., 1986). Here crabs were fully rehydrated and oxygen consumption had also returned to pre-

497 treatment levels within $24 \mathrm{~h}$. We did attempt to measure oxygen consumption during the initial

498 stages of rehydration (2- $6 \mathrm{~h}$ ), the problem being that this time period coincided with hours of

499 darkness. The animals became very active at dusk exhibiting a doubling of heart rate (McGaw et

500 al., 2018), and so the increase in activity masked any changes associated with rehydration.

501

502 Feeding preferences

503 When presented with a choice of food the crabs preferred fish and apple and consistently

504 consumed low quantities of lettuce. Land crabs show a strong preference for high nitrogen foods

505 such as carrion and animal faeces and will congregate around these food items in high numbers

506 (Wolcott \& Wolcott, 1984; Wolcott and O’Connor, 1992; Linton \& Greenaway, 2007). Fleshy

507 fruits contain a high proportion of living cells that are readily digestible and are preferred over 
508 leaf litter which has a higher carbon to nitrogen ratio and higher levels of cellulose (Linton \&

509 Greenaway, 2004). Therefore it is not surprising the crabs selected fish and apple, but ate low

510 amounts of lettuce. Erickson et al. (2008) also found that although the mangrove crab, Aratus

511 pisonii, primarily feeds on leaves in their natural habitat these are only eaten in very low

512 amounts when other food items are offered. This opportunistic omnivory is common in

513 herbivores and leaves are most likely only eaten as a necessity (Erickson et al., 2008; Nordhaus

514 et al., 2011). A selective preference for the high energy food type (when offered a choice)

515 therefore explains the low lettuce intake. However it does not explain why a low intake also

516 occurred when only lettuce was offered to the crabs (single choice experiments). Because lettuce

517 leaves are nutrient limited it might have been expected that crabs would show compensatory

518 feeding and eat more of them (Greenaway \& Raghaven, 1998). The reasons for this feeding

519 pattern are unclear. It is possible that compensatory feeding did not occur because lettuce leaves

520 are similar to the crab's natural diet of green leaves (which they were maintained on before

521 experiments) and they were exhibiting a negative preference induction whereby they preferred

522 novel items (Thacker, 1996, 1998). This has been observed in the land hermit crab Coenobita

523 compressus, which reduce intake of familiar foods, preferring novel items that may provide them

524 with essential nutrients and enhance growth (Thacker, 1998). An alternative explanation is that

525 land crab preference may not be solely dependent on nutrient content or novelty, but could be

526 based on other factors such as palatability or texture of the food (Nordhaus et al., 2011).

527 While we expected that as crabs became deprived of water they would choose food items

528 with a higher water content, instead crabs preferred the food with the higher energetic content,

529 irrespective of dehydration status. The crabs also consumed less of each food item and were less

530 likely to feed as dehydration levels increased, and this was most pronounced for the dry food 
531 items. This decrease in food intake could be due to several reasons. In dehydrated mammals a

532 lower food intake reflects a lower metabolism (Silanikove, 1994). This is unlikely to be the case

533 here for G. ruricola because although they exhibited a reduced oxygen consumption rate, it was

534 only after 8 days of dehydration and this appeared to be due a reduction in activity rather than a

535 down-regulation of metabolism. The reduced appetite in dehydrated mammals is also related to

536 the inability to produce adequate amounts of saliva (Silanikove 1994; Willmer et al., 2005;

537 Maloiy et al., 2008). Certainly in Gecarcinid crabs the gut plays a role in water storage (Mantel,

538 1968) and during dehydration water may be taken from the gut to replace that lost from the

539 hemolymph (Harris \& Kormanik, 1981). Since the foregut is the site of food processing and

540 requires the input of gastric juices this seems a likely explanation of why the dehydrated crabs

541 ate less food, especially dry food items (McGaw \& Curtis, 2013). In addition, as crabs lose water

542 the hemolymph osmolality increases (Harris \& Kormanik 1981). When dehydrated, crabs may

543 eat less because digested nutrients would be transported as amino acids and glucose which would

544 temporarily increase the osmolality of an already elevated hemolymph. The subsequent

545 intracellular catabolism of nutrients leads to the production of nitrogenous wastes and voiding

546 these wastes in the urine would also increase water loss (Harris, 1977). Dehydrated land crabs

547 may suspend processing of the meal, lowering protein catabolism and subsequent nitrogenous

548 waste production (Wood et al., 1986). We did notice that dehydrated crabs did take longer

549 produce faeces when dehydrated. However, this was probably only a slowing, rather than a total

550 suspension of digestion (McGaw \& Curtis, 2013). Gecarcinid crabs can tie up toxic ammonia as

551 urate crystals, removing it from the system and thus the need to produce urine excrete it (Linton

552 et al., 2017); these urate crystals can also function as a subsequent nitrogen store (Wolcott \&

553 Wolcott, 1984). However, in Cardisoma guanhumi (Wood et al., 1986) ammonia and urea levels 
554 increase over $72-84 \mathrm{~h}$, before declining, suggesting that the crabs are unable to convert

555 nitrogenous wastes to urates immediately. Thus, the decrease in amount of food consumed may

556 be a balance between the need to gain nutrients and metabolic water coupled with inability to

557 produce adequate gastric juices and to immediately store the nitrogenous wastes.

558 G. ruricola consumed considerably less dry than fresh food, irrespective of dehydration

559 status or food type. Cardisoma hirtipes also prefers fresh green leaves and flowers to older dryer

560 material; however if only dry brown leaves are available they actually eat more in order to

561 extract more nutrients (Greenaway \& Raghaven, 1998). Similar compensatory feeding was not

562 observed here, the wet food could simply be more palatable and food choice may also be based

563 upon texture and not just nutrient content (Nordhaus et al., 2011). This low intake of dry material

564 may have important implications for natural foraging: fresh leaves that fall and become available

565 to the crabs dry quickly (Kellman \& Delfosse 1993), and given a future drying scenario there

566 will likely be more dry leaf litter, but less of it being consumed by the crabs.

$567 \quad$ Finally there were differences in food preferences of non-dehydrated crabs as a function

568 of size. Smaller juvenile crabs ate more fish, while larger adult crabs consumed more apple; in

569 line with the other preference experiments, very little lettuce was consumed. Fleshy fruits are

570 often selected because they are easily digested (Linton \& Greenaway, 2004; 2007) coupled with

571 a relatively high energy content the apple may provide the necessary nutrients for adult crabs.

572 The herring had the highest protein and nitrogen content and since small crustaceans moult more

573 frequently it might be expected that they would require a higher protein and nitrogen intake

574 (Hartnoll, 1988). Indeed intermoult periods are lower and more growth likely occurs in land

575 crabs when they are not protein and nitrogen limited (Wolcott and Wolcott, 1984). 
577

578

579

580

581

582

583

584

585

586

587

588

589

590

591

592

593

594

595

596

597

598

599

\section{Ecological Implications}

Many land crab populations in the Caribbean have already been reduced by over

harvesting (Alayon, 2005; Baine et al., 2007), and the continued growth and urbanization in this region will only exacerbate the situation (Cincotta et al., 2000). If dehydration levels alter foraging patterns of G. ruricola, resulting in a lower food intake, this would ultimately slow growth leading to smaller, less healthy crabs (Wolcott \& Wolcott, 1984). A reduction in the fishery will further impact the expanding human population, because land crabs are an important source of protein and income for many Caribbean Islanders (Baine et al., 2007). Direct human impacts due to a reduction in crab numbers may however be less severe compared to potential trickle-down effects that the loss of land crabs would have on the environment. Gecarcinid land crabs can reach densities of 10,000 to 60,000 per hectare (Kellman \& Delfosse, 1993; Sherman, 2003); these animals have been described as ecosystem engineers because of their role in nutrient recycling and seedling recruitment (Lindquist et al., 2009). Land crabs are very important in forests because they feed upon and reduce surface leaf litter (Kellman \& Delfosse, 1993;

Sherman, 2003). They also bring food down into their burrows thereby enriching nutrient levels deeper in the soil (Sherman, 2006). Leaf litter rapidly builds-up in areas absent of crabs, preventing seedlings from germinating, altering soil nutrient patterns and preventing precipitation soaking into the soil (Kellman \& Delfosse, 1993; Sherman, 2003; Lindquist et al., 2009). Land crabs also prey selectively on seedlings and fruit and as such dictate the diversity of species that can become established (Green et al., 1997; Sherman, 2002: Capistran-Barradas \& Morena-Casasola, 2006; Lindquist et al., 2009).

Although a reduction in precipitation levels might lead to changes in land crab foraging activity that will affect nutrient balances and floral diversity (O'Dowd \& Lake, 1989; Capistran- 
600 Barradas \& Morena-Casasola, 2006; Lindquist et al., 2009), such ecosystem changes are unlikely

601 to be driven by changes in crab foraging alone (Parmesan and Hanley, 2015). The decrease in

602 available water for the plants will also play a major role in shaping coastal forests. Predictions

603 vary as to whether there will be a shift in plant species richness, or whether plant communities

604 will adapt to periods of drought (Engelbrecht et al., 2007). Nonetheless, the current literature

605 suggests the predicted drying will lead to a slower growth rate, particularly in saplings, and a loss

606 of $30-40 \%$ of plant biomass (Allen et al., 2017). The reduced rainfall will lead to a bottleneck of

607 periods when seedlings can germinate (McLaren \& McDonald. 2003), while predation by crabs

608 will further reduce the numbers of seedlings that become established (Capistran-Barradas \&

609 Morena-Casasola, 2006; Lindquist et al., 2009). A reduction in precipitation also limits the

610 transfer of soil nutrients for plants, especially nitrogen (Allen et al., 2017); this will likely be

611 further compounded by the reduced turnover of surface nutrients by the crabs (Sherman, 2006).

612 Thus there is complexity in how this ecosystem will responds to future climate change,

613 suggesting that this system is compelling for research on species interactions and ecosystem

614 functioning in a warmer and drier climate.

615

616 Conclusions

617 Black land crabs, Gecarcinus ruricola could withstand a body water loss of $23 \pm 2 \%$ and

618 survive for between 13 and $16 \mathrm{~d}$ without access to water. The crabs consistently chose the food

619 with the higher energetic content irrespective of dehydration status. However, an increase in

620 dehydration levels led to a reduction in food intake in G. ruricola and this was especially

621 noticeable for dry food. This lower food intake likely occurred because loss of water from the

622 gut would hamper digestive processes. Land crabs are important ecosystem engineers and the 
623 predicted decrease in Caribbean rainfall could have important trickle down effects on coastal

624 forest ecosystems.

625

626

627

628

629 Acknowledgments

630 We would like to thank the director and staff of the Cape Eleuthera Institute for their help and 631 use of facilities. We also thank Dr. Stuart Linton, Deakin University, for helpful discussion.

632

633

634

635

636

637

638

639

640

641

642

643

644

645 
654 Literature cited

655 Alayon LH. 2005. External regulations and local appropriations in the management of a resource 656 in Old Providence and Santa Catalina Islands. Survival of the commons: Mounting challenges 657 and new realities. $11^{\text {th }}$ Conference of the international association for the study of common 658 property pp 25

659

660 Allen K, Dupuy JM, Gei MG, Hulshof C, Medvig D, Pizano C, Salgado-Negret B, Smith CM, 661 Trierweiler A, Van Bloem SJ, Waring BG, Xu X, Powers JS. 2017. Will seasonally dry tropical 662 forests be sensitive or resistant to future changes in rainfall regimes? Environmental Research 663 Letters. 12: 023001

664

665 Ansell AD. 1973. Changes in oxygen consumption, heart rate and ventilation accompanying 666 starvation in the decapod crustacean Cancer pagurus. Netherlands Journal of Sea Research. 7: $667 \quad 455-475$ 
669 Baine B, Howard M, Taylor E, James J, Velasco A, Grandas Y, Hartnoll R. 2007. The

670 development of management options for the black land crab (Gecarcinus ruricola) catchery in

671 the San Andres Archipelago, Colombia. Ocean and Coastal Management. 50: 564-589

672

673 Bellard C, Bertelsmeier C, Leadley P, Thuiller W, Courchamp F. 2012. Impacts of climate

674 change on the future of biodiversity. Ecology Letters 15: 365-377

675

676 Bergamino L, Richoux NB. 2015. Food preferences of the estuarine crab Sesarma catenata

677 estimated through laboratory experiments. Marine and Freshwater Research. 66: 750-756

678

679 Bliss DE, Wang SM, Martinez EA. 1966. Water balance in the land crab, Gecarcinus lateralis, 680 during the intermolt cycle. American Zoologist. 6: 197-212

681

682

Bliss DE. 1968. Transition from water to land in decapod crustaceans. American Zoologist. 8:

$683 \quad 355-392$

684

685

Bliss DE, Van Montfrans J, Van Montfrans M, Boyer JR. 1978. Behavior and growth of the land 686 crab Gecarcinus lateralis (Fréminville) in southern Florida. Bulletin of the American Museum of 687 Natural History. 160: 111-152

688

689 Britton, J.C., G.C. Kroh, and C. Golightly. 1982. Biometric and ecological relationships in two 690 sympatric Caribbean Gecarcinidae (Crustacea: Decapoda). J. Crust. Biol. 2: 207-222

691 
692 Burggren WW, McMahon BR. 1981. Oxygen uptake during environmental temperature change 693 in hermit crabs: Adaptation to subtidal, intertidal and supratidal habitats. Physiological Zoology. $69454: 5-33$

695

696 Campbell JD, Taylor MA, Stephenson TS, Watson RA, Whyte FS. 2011. Future climate of the 697 Caribbean from a regional climate model. International Journal of Climatology. 31: 1866-1878 698

699 Capistran-Barradas A, Morena-Casasola P. 2006. Postdispersal fruit and seed removal by the 700 crab Gecarcinus lateralis in a coastal forest in Veracruz, Mexico. Biotropica. 38: 1-7

701

702 Chace FA, Hobbs HH. 1969. The freshwater and terrestrial decapod crustaceans of the West 703 Indies with special reference to Dominica. Bulletin of the U.S. National Museum. 292: 1-258 704

705 Chen AA, McTavish RJ, Taylor MA, Marx L. 1997. Using SST anomalies to predict flood and 706 drought conditions for the Caribbean. COLA. Report 49

708 Christensen JH, Hewitson B, Busuioc A, Chen A, Gao X, Held I, Jones R, Kolli RK, Kwon WT, 709 Laprise R, Magaña Rueda V, Mearns L, Menéndez CG, Räisänen J, Rinke A, Sarr A, Whetton P. 710 2007. Regional climate projections. In: Climate Change 2007: the physical science basis.

711 Contribution of working group I to the fourth assessment report of the intergovernmental panel 712 on climate change. Cambridge University Press, Cambridge and New York 713 
714 Ciabatta L, Massari C, Brocca L, Gruber A, Reimer C, Hahn S, Paulik C, Dorigo W, Kidd R,

715 Wagner W. 2017. SM2RAIN-CCI: A new global long-term rainfall data set derived from ESA

716 CCI soil moisture. Earth Systems Science Data Discussion. 2017: 1-23

717

718 Cincotta RP, Wisnewski J, Engelman L. 2000. Human population in the biodiversity hotspots.

719 Nature Letters. 404: 990-992

720

721 Donat MG, Lowry AL, Alexander LV, O’Gorman PA, Maher N. 2016. More extreme

722 precipitation in the world's dry and wet regions. Nature Climate Change. 6: 508-513

723

724 Engelbrecht BM, Comita LS, Condit R, Kursar TA, Tyree MT, Turner BL, Hubbell SP. 2007.

725 Drought sensitivity shapes species distribution patterns in tropical forests. Nature Letters. 447:

$726 \quad 80-82$

727

728

Erickson AA, Feller IC, Paul VJ, Kwiatkowski LM, Lee W. 2008. Selection of an omnivorous

729

diet by the mangrove tree crab Aratus pisonii in laboratory experiments. Journal of Sea

730

Research. 59: 59-69

731

732 Flemister LJ. 1958. Salt and water anatomy, constancy and regulation in related crabs from

733 marine and terrestrial habitats. Biological Bulletin. 115: 180-200

734

735 Fimpel E. 1975. On the adaptation of terrestrial and semiterrestrial Brachyura from the Brazil

736 coast. Zoologische Jahrbücher Abteilung für Systematik, Geographie und Biologie der Tiere. 
739 Gifford CA. 1962. Some observations on the general biology of the land crab Cardisoma

740 guanhumi (Latreille), in south Florida. Biological Bulletin. 123: 207-223

741

742 Green PT, O’Dowd DJ, Lake PS. 1997. Control of seedling recruitment by land crabs in rain

743 forest on a remote oceanic island. Ecology. 78: 2474-2486

745 Greenaway P, Raghaven S. 1998. Digestive strategies in two species of leaf-eating land crabs

746 (Brachyura: Gecarcinidae) in a rain forest. Physiological Zoology. 71: 36-44

747

748 Greenaway P, Bonaventura J, Taylor HH. 1983. Aquatic gas exchange in the freshwater land 749 crab Holthuisana quadratus. Journal of Experimental Biology. 103: 225-236

750

751 Griffiths ME, Basma MA, Vega A. 2007. Dry season distribution of land crabs, Gecarcinus

752 quadratus (Crustacea: Gecarcinidae), in Corcovado National Park, Costa Rica Rev. Biologia

753 Tropica. 55: 219-224

754

755 Hall TC, Sealy AM, Stephenson TS, Kusunoki S, Taylor MA, Chen A, Kitoh A. 2013. Future 756 climate of the Caribbean from a super-high-resolution atmospheric general circulation model.

757 Theoretical and Applied Climatology. 113: 271-287 758 
759 Harris RR. 1977. Urine production rate and water balance in the terrestrial crabs Gecarcinus

760 lateralis and Cardisoma guanhumi. Journal of Experimental Biology. 68: 57-67

761

762 Harris R.R, Kormanik GG. 1981. Salt and water balance and antennal gland function in three

763 Pacific species of terrestrial crab (Gecarcoidea lalandii, Cardisoma carnifex, Birgus latro). II.

764 The effects of desiccation. Journal of Experimental Zoology. 218: 107-116

765

766 Hartnoll RG. 1988. Evolution, systematics, and geographical distribution. In: Burggren WW,

767 McMahon BR. (eds) Biology of the land crabs. Cambridge University Press, Cambridge, pp 6$768 \quad 54$

769

770 Hartnoll RG, Baine MS, Grandas Y, James J, Atkin H. 2006. Population biology of the black

771 land crab, Gecarcinus ruricola, in the San Andre' s Archipelago, western Caribbean. Journal of

772 Crustacean Biology. 26: 316-325

773

774 Hartnoll R, Clark PF. 2006. A mass recruitment event in the land crab Gecarcinus ruricola

775 (Linnaeus, 1758) (Brachyura: Grapsoidea: Gecarcinidae), and a description of the megalopa.

776 Zoological Journal of the Linnaen. Society. 146: 149-164

777

778 Herreid CF. 1963. Observations on the feeding behavior of Cardisoma guanhumi (Latreille) in

779 Southern Florida. Crustaceana. 5: 176-180

780 
781 Herreid, CF. 1969. Water loss of crabs from different habitats. Comparative Biochemistry and

782 Physiology. 28A: 829-839

783

784 Jiménez C, Ortega-Rubio A, Álvarez-Cárdenas S, Arnaud G. 1994. Ecological aspects of the

785 land crab Gecarcinus planatus (Decapoda: Gecarcinidae) in Socorro Island, Mexico. Biological

786 Conservation. 69: 9-13

787

788 Kellman M, Delfosse B. 1993. Effect of the red land crab (Gecarcinus lateralis) on leaf litter in a

789 tropical dry forest in Veracruz, Mexico. Journal of Tropical Ecology. 9: 55-65

790

791 Lindquist ES, Krauss KW, Green PT, O’Dowd DJ, Sherman PM Smith TJ. 2009. Land crabs as

792 key drivers in tropical coastal forest recruitment. Biological Reviews. 84: 203-233

793

794 Linton SM, Greenaway P. 2004. Presence and properties of cellulase and hemicellulase enzymes

795 of the gecarcinid land crabs, Gecarcoidea natalis and Discoplax hirtipes. Journal of

796 Experimental Biology. 306: 4095-4104

797

798 Linton SM, Greenaway P. 2007. A review of feeding and nutrition of herbivorous land crabs:

799 adaptations to low quality plant diets. Journal of Comparative Physiology. B. 177: 269-286

800

801 Linton SM, Wright JC, Howe CG. 2017. Nitrogenous waste metabolism within terrestrial

802 Crustacea, with special reference to purine deposits and their metabolism., In. Acid-base balance 
803 and nitrogen excretion in invertebrates D. Weihrauch, M. O’Donnell (eds.). Springer

804 International Publishing Switzerland

805

806 Maloiy GMO, Kanui TI, Towett PK, Wambugu SN, Miaron JO Wanyoike MM. 2008. Effects of

807 dehydration and heat stress on food intake and dry matter digestibility in East African ruminants.

808 Comparative Biochemistry and Physiology. 151A: 185-190

809

810 Mantel LH. 1968. The foregut of Gecarcinus lateralis as an organ of salt and water balance.

811 American Zoologist. 8: 433-442

812

813 Mchenga ISS, Tsuchiya M. 2010. Feeding choice and the fate of organic materials consumed by

814 Sesarma crabs Perisesarma bidens (De Haan) when offered different diets. Journal of Marine

815 Biology. 2010: 1-10

816

817 McLaren K, McDonald M. 2003. The effects of moisture and shade on seed germination and

818 seedling survival in a tropical dry forest in Jamaica. Forest Ecology Management. 183: 61-75

819

820 McGaw IJ. 2005. Does feeding limit cardiovascular modulation in the Dungeness crab Cancer

821 magister during hypoxia? Journal of Experimental Biology. 208: 83-91

822

823 McGaw IJ. 2007. The interactive effects of exercise and feeding on oxygen uptake, activity

824 levels and gastric processing in graceful crab, Cancer gracilis. Physiological and Biochemical

825 Zoology. 80: 335-343 
827 McGaw IJ, Curtis DL. 2013. A review of gastric processing in decapod crustaceans. Journal of

828 Comparative Physiology. B. 183: 443-465

829

830 McGaw IJ, Steell SC, Van Leeuwen TE, Eliason EJ, Cooke SJ. 2018. Application of miniature

831 heart-rate data loggers for use in free moving decapod crustaceans: method development and

832 validation. Physiological and Biochemical Zoology. 91: 731-739

833

834 Nordhaus I, Salewski T, Jennerjahn T. 2011. Food preferences of mangrove crabs related to leaf

835 nitrogen compounds in the Segara Anakan lagoon, Java, Indonesia. Journal of Sea Research. 65:

$836 \quad 414-426$

837

838 Nurse LA, Sem G. 2001. Small island states. In Climate change: the scientific basis.

839 Contribution of working group 1 to the third assessment report of the intergovernmental panel on

840 climate change (IPCC). Houghton. JT et al (eds). Cambridge University Press: Cambridge, UK.

841

842 O’Dowd DJ, Lake PS. 1989. Red crabs in rainforest, Christmas Island: removal and relocation of

843 leaf-fall. Journal of Tropical Ecology. 5: 337-348

844

845 Ortega-Rubio A, Jímenez ML, Llinas J, Arnaud G. 1997. Some ecological aspects of the land

846 crab, Gecarcinus planatus Stimpson, at Socorro Island, Colima, Mexico. Arizona-Nevada.

847 Academy of Science. 30: 17-22

848 
849 Palmer JD. 1971. Comparative studies of circadian locomotory rhythms in four species of

850 terrestrial crabs. American Midland Naturalist. 85: 97-107

851

852 Parmesan C, Hanley ME. 2015. Plants and climate change: Complexities and surprises Annals of 853 Botany. 116: 849-864

854

855 Peterson CH, Reynaud PE. 1989. Analysis of feeding preference experiments. Oecologia. 80: $856 \quad 82-86$

857

858 Pinheiro J, Bates D, DebRoy S, Sarkar D, Team RC. 2017. nlme: Linear and Nonlinear Mixed 859 Effects Models. R package version 3. 1-131

860

861 Secor SM. 2009. Specific dynamic action: a review of the postprandial metabolic response.

862 Journal of Comparative Physiology. B. 179: 1-56

863

864 Sherman PM. 2002. Effects of land crabs on seedling densities and distributions in a mainland 865 neotropical forest. Journal of Tropical Ecology. 18: 67-89

866

867 Sherman PM. 2003. Effects of land crabs on leaf litter distributions and accumulations in a 868 mainland tropical rainforest. Biotropica. 35: 365-374

869 
870 Sherman PM. 2006. Influence of land crabs Gecarcinus quadratus (Gecarcinidae) on

871 distributions of organic carbon and roots in a Costa Rican rain forest. Revisita Biologica Tropica.

872 54: 149-161

873

874 Silikanove N. 1994. The struggle to maintain hydration and osmoregulation in animals

875 experiencing severe dehydration and rapid rehydration: The story of ruminants. Experimental

876 Physiology. 79: 281-300

877

878 Steinke TD, Rajh A, Holland AJ. 1993. The feeding behavior of the red mangrove crab Sesarma

879 meinerti de Man, 1887 (Crustacea: Decapoda: Grapsidae) and its effect on the degradation of

880 mangrove leaf litter. South African Journal of Marine Science. 13: 151-160

881

882 Taylor AC, Davies PS. 1981. Aquatic respiration in the land crab, Gecarcinus lateralis

883 (Friminville). Comparative Biochemistry and Physiology. 72A: 683-688

884

885 Taylor MA, Stephenson TS, Owino A, Chen AA, Campbell JD. 2011. Tropical gradient

886 influences on Caribbean rainfall. Journal of Geophysical Research. 116: 1-8

887

888 Taylor MA, Whyte FS, Stephenson TS, Campbell JD. 2013. Why dry? Investigating the future

889 evolution of the Caribbean low level jet to explain projected Caribbean drying. International

890 Journal of Climatology 32: 119-128

891 
892 Taylor MA, Clarke LA, Centella A, Bezanilla A, Stephenson TS, Jones JJ, Campbell JD, Vichot 893 A, Charlery J. 2018. Future Caribbean climates in a world of rising temperatures: The 1.5 vs 2.0 894 dilemma. Journal of Climate. 31: 71-89

895

896 Thacker RW. 1996. Food choices of land hermit crabs (Coenobita compressus H. Milne

897 Edwards) depend on.past experience. Journal of Experimental Marine Biology and Ecology 199: $898 \quad 179-191$.

899

900 Thacker RW. 1998. Avoidance of recently eaten foods by land hermit crabs, Coenobita

901 compressus. Animal Behaviour. 55: 485-496

902

903 Team RC. 2017. R: A Language and Environment for Statistical Computing. Vienna, Austria. 904

905 Terblanche JS, Overgaard J. 2015. Introduction to the Special Issue "What sets the limit? How

906 thermal limits, performance and preference in ectotherms are influenced by water or energy

907 balance". Journal of Thermal Biology. 54: 1-2

908

909 Venables WN, Ripley BD. 2002. Modern Applied Statistics with S. Springer, New York.

910

911 Wallace JC. 1973. Feeding, starvation and metabolic rate in the shore crab Carcinus maenas

912 Marine Biology. 20: 277-281

913 
914 Weinstein RB, Full RJ, Ahn AN. 1994. Moderate dehydration decreases locomotor performance 915 of the ghost crab, Ocypode quadrata. Physiological and Biochemical Zoology. 67: 873-891

916

917 Willmer P, Stone G, Johnston I. 2005. Environmental physiology of animals. $2^{\text {nd }}$ edition

918 Blackwell publishing. Victoria Australia. 764pp

919

920 Wolcott TG. 1988. Ecology. In: Burggren WW, McMahon BR. (eds) Biology of the land crabs.

921 Cambridge University Press, Cambridge

922

923 Wolcott, TG. 1992. Water and solute balance in the transition to land. American Zoologist. 32:

$924 \quad 428-437$

925

926 Wolcott DL, O’Connor NJ. 1992. Herbivory in crabs: adaptations and ecological considerations.

927 American Zoologist. 32: 370-381

928

929 Wolcott DL, Wolcott TG. 1984. Food quality and cannibalism in the red land crab Gecarcinus

930 lateralis. Physiological Zoology. 57: 318-324

931

932 Wolcott DL, Wolcott TG. 1987. Nitrogen limitation in the herbivorous land crab Cardisoma

933 guanhumi. Physiological Zoology. 60: 262-268

934 
935 Wolcott TG, Wolcott DL. 1988. Availability of salts is not a limiting factor for the land crab 936 Gecarcinus lateralis (Freminville). Journal of Experimental Marine Biology and Ecology 121:

$937 \quad 193-207$

938

939 Wood CM, Boutilier RG, Randall DJ. 1986. The physiology of dehydration stress in the land

940 crab, Cardisoma carnifex: respiration, ionoregulation, acid-base balance and nitrogenous waste

941 excretion. Journal of Experimental Zoology. 126: 271-296

942

943 Wong BBM. Candolin U. 2015. Behavioral responses to changing environments. Behavioural

944 Ecology. 26: 665-673

945

946

947

948

949

950

951

952

953

954

955

956

957 
961

962

963

964

965

966

967

968 Figure Legends

969

970 Table 1. Regression statistics and equations for changes in mass of the three fresh and dry food

971 types after $12 \mathrm{~h}$ in air at $25 \pm 2^{\circ} \mathrm{C}$. These were used to calculate the mass eaten and for

972 converting all masses eaten to a dry mass.

973

974 Table 2. Maximal metabolic rate $\left(\mathrm{mg} \mathrm{O}_{2} \mathrm{~kg} \mathrm{~h}^{-1}\right)$ and the scope of the response (maximal

975 metabolic rate/resting metabolic rate) of land crabs following 0, 4 and 8 days of dehydration

976 followed by recovery, $R$ after 1 day access to water. The values represent the mean \pm SEM of 8

977 animals; different letters denote significant differences at $\mathrm{P}<0.05$.

978

979 Table 3. Food consumption of single fresh and dried food items. The following factors were

980 included in a generalized linear Poisson regression: days dehydration ( 0,4 and 8), food type 
981 (lettuce, apple, and fish), moisture level (fresh, dry) and interactions between: food type*days 982 dehydration, days dehydration*moisture level, and moisture level*food type. The "Intercept" is

983 the reference and represents Day0, Lettuce, Wet - all treatments are contrasted against the 984 reference. $\mathrm{SE}=$ Standard Error, Value $=$ Coefficient Estimate, $\mathrm{ci}=$ Confidence Interval. Residual 985 deviance $=15622$ on 238 degrees of freedom. The data were based on 14 individual crabs for 986 each food type and each dehydration level monitored in separate containers.

987

988 Table 4. Number of animals feeding (total of 14) on fresh or dry lettuce, apple, or fish when 989 offered a single choice of each item as a function of being dehydrated for 0,4 or 8 days. The data 990 represent a total of 14 animals (with 1 animal per experimental container) per food item and 991 different animals were used for each food item and each dehydration level.

992

993 Table 5. Multiple choice experiment. The following factors were included in a generalized linear 994 Poisson regression: days dehydration ( 0,4 and 8$)$ and food type (lettuce, apple, and fish) and 995 interactions between: food type*days dehydration. The "Intercept" is the reference and 996 represents Day 0, Lettuce - all treatments are contrasted against the reference. SE $=$ Standard

997 Error, Value $=$ Coefficient Estimate, $\mathrm{ci}=$ Confidence Interval, $\%$ diff $=$ percentage change

998 Residual deviance $=10697$ on 117 degrees of freedom. The data were based on 14 individual 999 crabs at each dehydration level monitored in separate containers.

1001 Table 6. Number of animals feeding (total of 14) when offered a multiple choice of fresh lettuce, 1002 apple, or fish as a function of being dehydrated for 0,4 or 8 days. The data represent a total of 14 
1003 (different) crabs, for each dehydration level (each crab was held separately in an experimental 1004 chamber).

1005

1006 Table 7. Effect of crab size on food preference. An individual crab was held in the experimental

1007 chamber and offered the 3 food types. A general least-squares regression included crab body 1008 mass and food type (lettuce, apple, and fish), with an interaction term. The "Intercept" is the 1009 reference and represents "Lettuce" for crabs with 0 mass - all treatments are contrasted against

1010 the reference. A different standard deviation per food type was modelled (using a weights

1011 function as described in the methods) with a ratio of Lettuce=1.000, Apple=1.146, and

1012 Fish=0.126. SE $=$ Standard Error, Value $=$ Coefficient Estimate. Degrees of freedom $=162$.

1013

1014 Figure 1. Black land crabs, Gecarcinus ruricola, emerged after rains in large numbers. This was

1015 the only time they were observed in the open during daylight hours. The crabs congregated

1016 around standing pools of freshwater and were observed drinking by scooping water with the

1017 chelae (photograph - Iain McGaw).

1018

1019 Figure 2. Boxplot of the number of consecutive days per month without rain in a $0.25^{\circ}$ grid

1020 surrounding the Cape Eleuthera Institute for the years 1998 to 2015 inclusive. Data was gathered 1021 from the new global scale rainfall product, SM2RAIN-CCI. Mean levels for each month are

1022 shown as a solid square and the open circles are statistical outliers (values either greater than

1023 upper or lower quartile $+1.5 *$ interquartile difference).

1024 
1025 Figure 3. Water loss (expressed as percent body mass loss) of black land crabs G. ruricola held

1026 in perforated plastic containers inside the crab hutch (solid lines, $n=8$ ) and in wire mesh

1027 containers in the laboratory (dashed line, $n=10$ ). The former treatment was designed to mimic the

1028 burrow environment of the crabs, and animals were maintained in these conditions until all had

1029 succumb from water loss. The data represent the mean $\pm \mathrm{SEM}$.

1030

1031 Figure 4. Resting oxygen consumption rates $\left(\mathrm{mg} \mathrm{O}_{2} \mathrm{~kg} \mathrm{~h}^{-1}\right)$ of 8 hydrated and 8 dehydrated

1032 black land crabs $G$. ruricola over a period of $8 \mathrm{~d}$, followed by $1 \mathrm{~d}$ of recovery with free access to

1033 water. The data represent the mean \pm SEM, asterisks denote significant differences between the

1034 hydrated and dehydrated crabs $(\mathrm{P}<0.05)$.

1035

1036 Figure 5. Boxplots showing amount of a) fresh lettuce, apple, or fish and b) dry lettuce, apple,

1037 and fish (\% dry mass as a function of animal dry mass) consumed by land crabs when offered

1038 just one food item after they had been deprived of water for 0,4 or 8 days. The solid symbols in

1039 the bars represent the adjusted means derived from the model coefficients and the smaller open

1040 circles are the statistical outliers (values either greater than upper or lower quartile $+(1.5 *$

1041 interquartile difference)). Note the different scales on the y-axis for the fresh and dry food. The

1042 data was derived from 14 different individual animals (held in separate experimental feeding

1043 chambers) for each food type and dehydration level treatment

1044

1045 Figure 6. Boxplots showing amount of fresh lettuce, apple, or fish consumed (\% dry mass as a

1046 function of animal dry mass) by land crabs when offered a multiple choice of all 3 items after

1047 they had been deprived of water for 0,4 or 8 days. The solid symbols in the bars represent the 
1048 adjusted means derived from the model coefficients and the smaller open circles are the

1049 statistical outliers (values either greater than upper or lower quartile $+(1.5 *$ interquartile

1050 difference)). The data was derived from 14 different individual animals (each held in a separate

1051 experimental chamber) for each dehydration level treatment. All 3 food items were offered in

1052 excess in order to ensure crabs did not consume all of one food item and then just move onto the

1053 next item.

1054

1055 Figure 7. Amount of fresh lettuce, apple, or fish consumed (\% dry mass as a function of animal

1056 dry mass) of land crabs varying in size between $25 \mathrm{~g}$ and $475 \mathrm{~g}$ when offered a multiple choice of

1057 the 3 food items. Each crab was maintained it a separate experimental container and the food

1058 items were offered in excess in order to maintain a multiple-choice of food items throughout the

$105912 \mathrm{~h}$ experimental period. Only fully hydrated crabs were used in this experiment. 


\section{Figure 1}

Photo of crabs drinking at a pool

Black land crabs, Gecarcinus ruricola, emerged after rains in large numbers. This was the only time they were observed in the open during daylight hours. The crabs congregated around standing pools of freshwater and were observed drinking by scooping water with the chelae (photograph - lain McGaw).

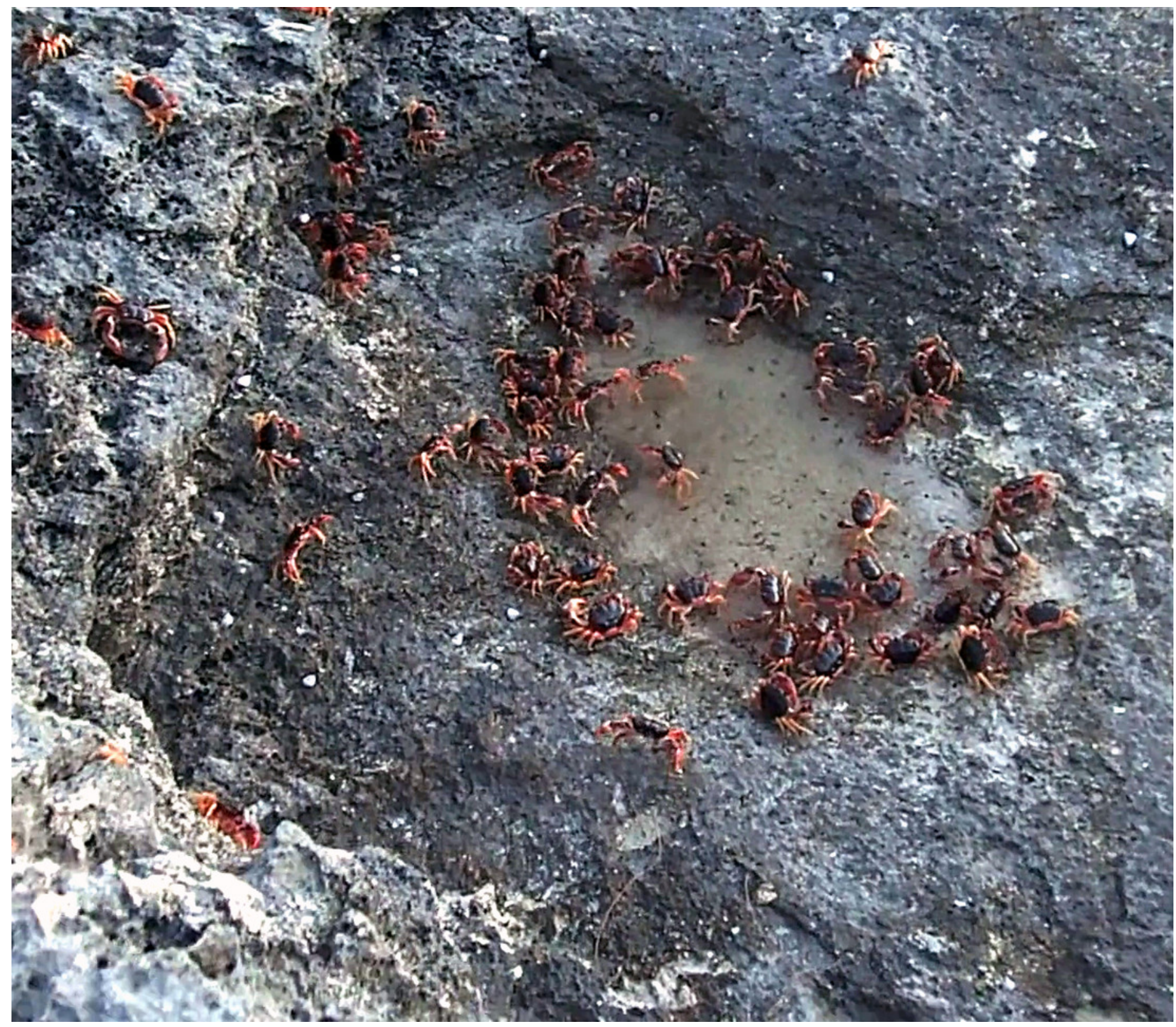


Figure 2

Rainfall data

Boxplot of the number of consecutive days per month without rain in a $0.25^{\circ}$ grid surrounding the Cape Eleuthera Institute for the years 1998 to 2015 inclusive. Data was gathered from the new global scale rainfall product, SM2RAIN-CCI. Mean levels for each month are shown as a solid square and the open circles are statistical outliers (values either greater than upper or lower quartile $+1.5 *$ interquartile difference). 


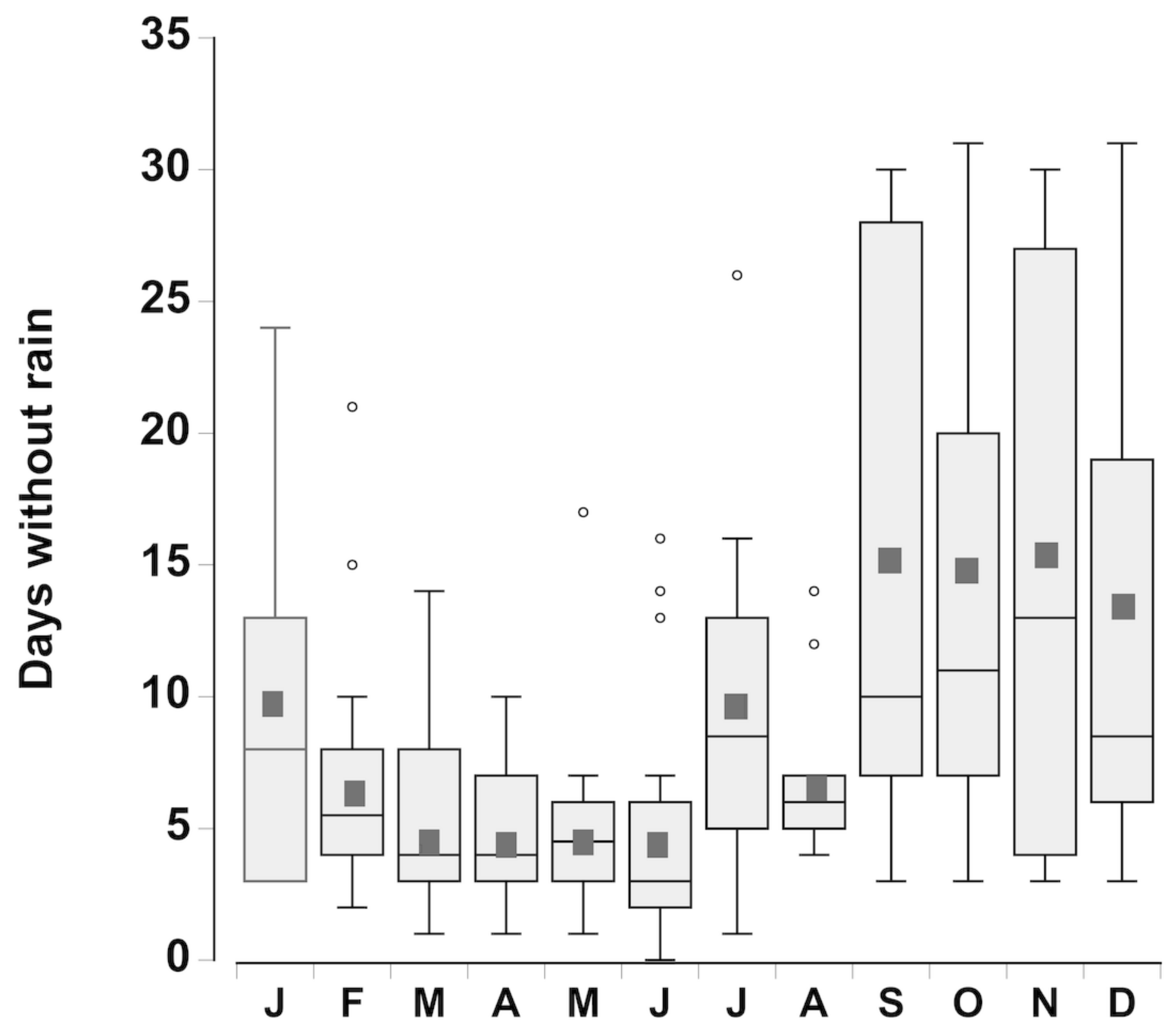


Figure 3

Figure 3. Water loss in land crabs

Water loss (expressed as percent body mass loss) of black land crabs $G$. ruricola held in perforated plastic containers inside the crab hutch (solid lines, $n=8$ ) and in wire mesh containers in the laboratory (dashed line, $n=10$ ). The former treatment was designed to mimic the burrow environment of the crabs, and animals were maintained in these conditions until all had succumb from water loss. The data represent the mean + SEM.

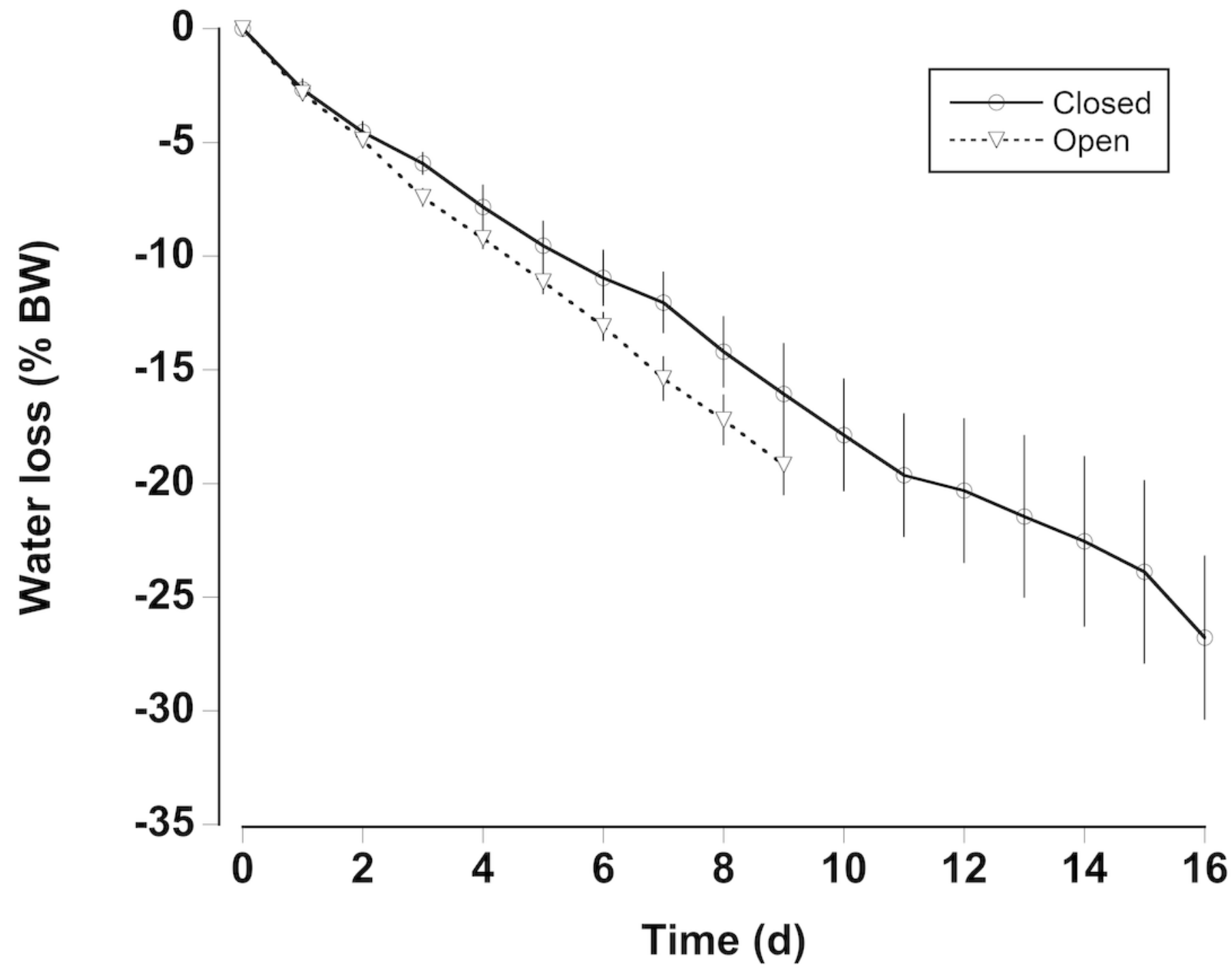


Figure 4

Oxygen consumption rates with dehydration

Resting oxygen consumption rates $\left(\mathrm{mg} \mathrm{O}_{2} \mathrm{~kg} \mathrm{~h}^{-1}\right)$ of 8 hydrated and 8 dehydrated black land crabs $\mathrm{G}$. ruricola over a period of $8 \mathrm{~d}$, followed by $1 \mathrm{~d}$ of recovery with free access to water. The data represent the mean + SEM, asterisks denote significant differences between the hydrated and dehydrated crabs $(P<0.05)$.

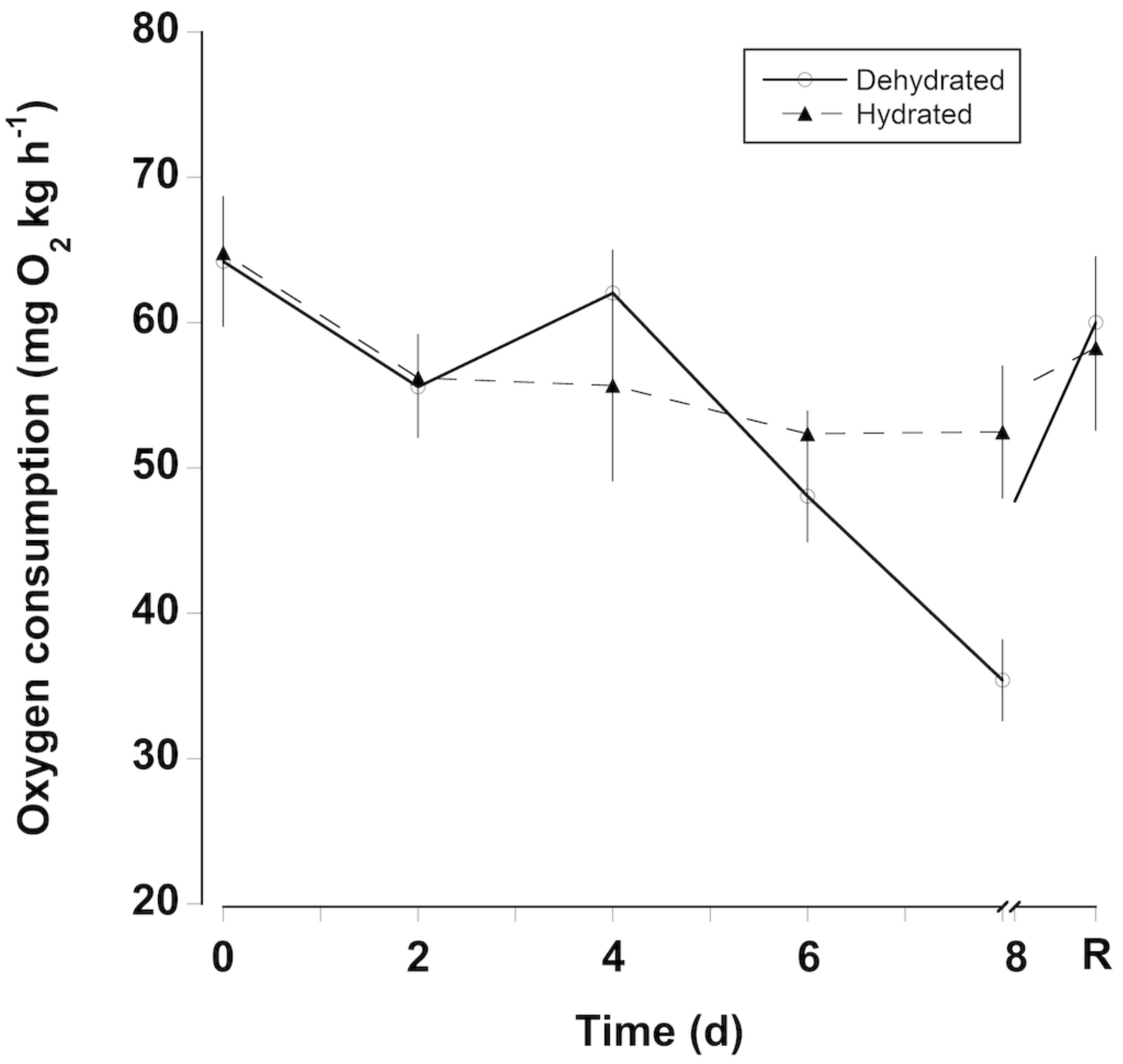




\section{Figure 5}

Feeding on wet and dry foods

Boxplots showing amount of a) fresh lettuce, apple, or fish and b) dry lettuce, apple, and fish (\% dry mass as a function of animal dry mass) consumed by land crabs when offered just one food item after they had been deprived of water for 0,4 or 8 days. The solid symbols in the bars represent the adjusted means derived from the model coefficients and the smaller open circles are the statistical outliers (values either greater than upper or lower quartile $+(1.5 *$ interquartile difference)). Note the different scales on the $y$ axis for the fresh and dry food. The data was derived from 14 different individual animals (held in separate experimental feeding chambers) for each food type and dehydration level treatment 

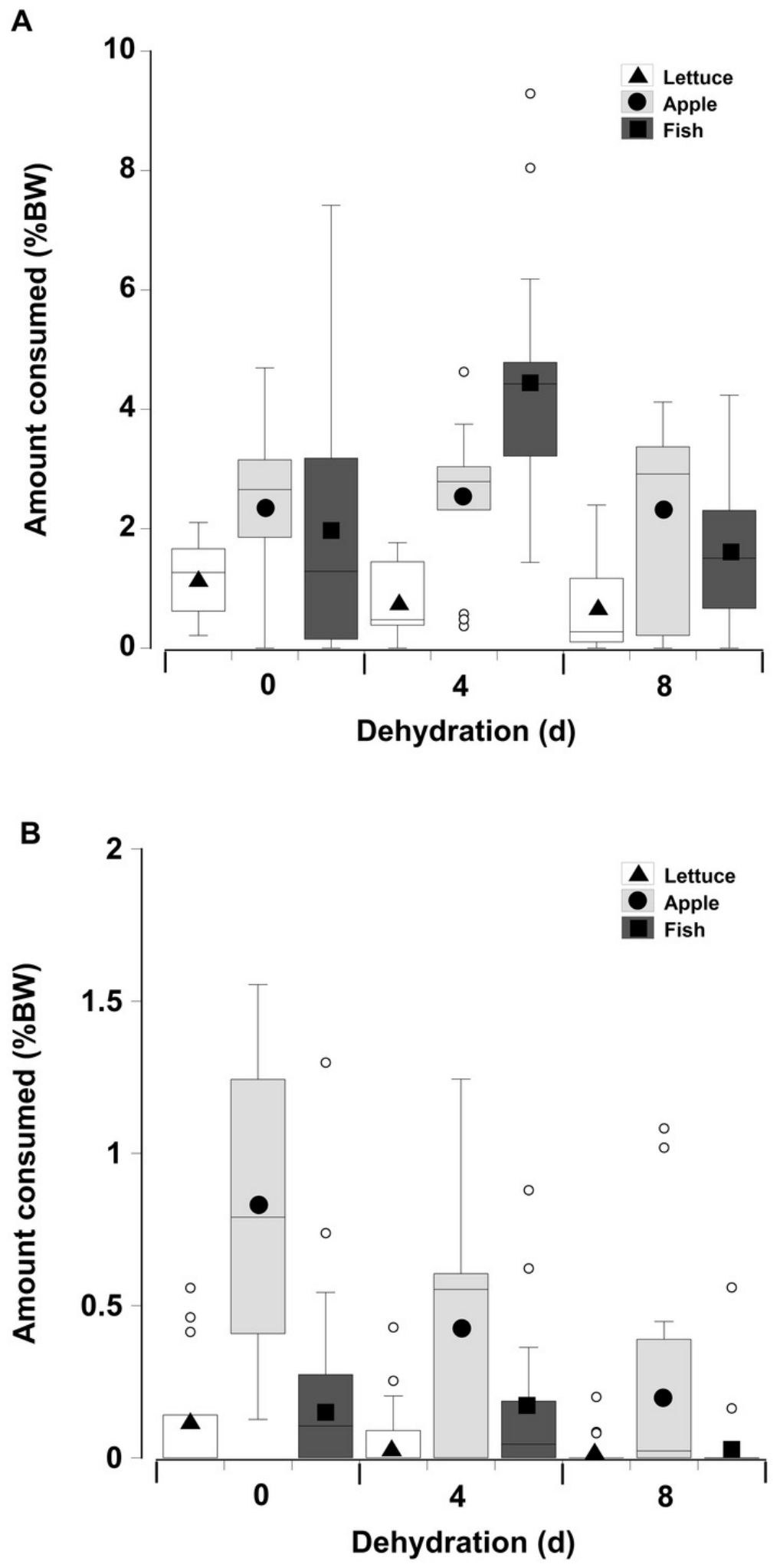


\section{Figure 6}

\section{Multiple choice of items offered to land crabs}

Boxplots showing amount of fresh lettuce, apple, or fish consumed (\% dry mass as a function of animal dry mass) by land crabs when offered a multiple choice of all 3 items after they had been deprived of water for 0,4 or 8 days. The solid symbols in the bars represent the adjusted means derived from the model coefficients and the smaller open circles are the statistical outliers (values either greater than upper or lower quartile $+(1.5 *$ interquartile difference) $)$. The data was derived from 14 different individual animals (each held in a separate experimental chamber) for each dehydration level treatment. All 3 food items were offered in excess in order to ensure crabs did not consume all of one food item and then just move onto the next item. 


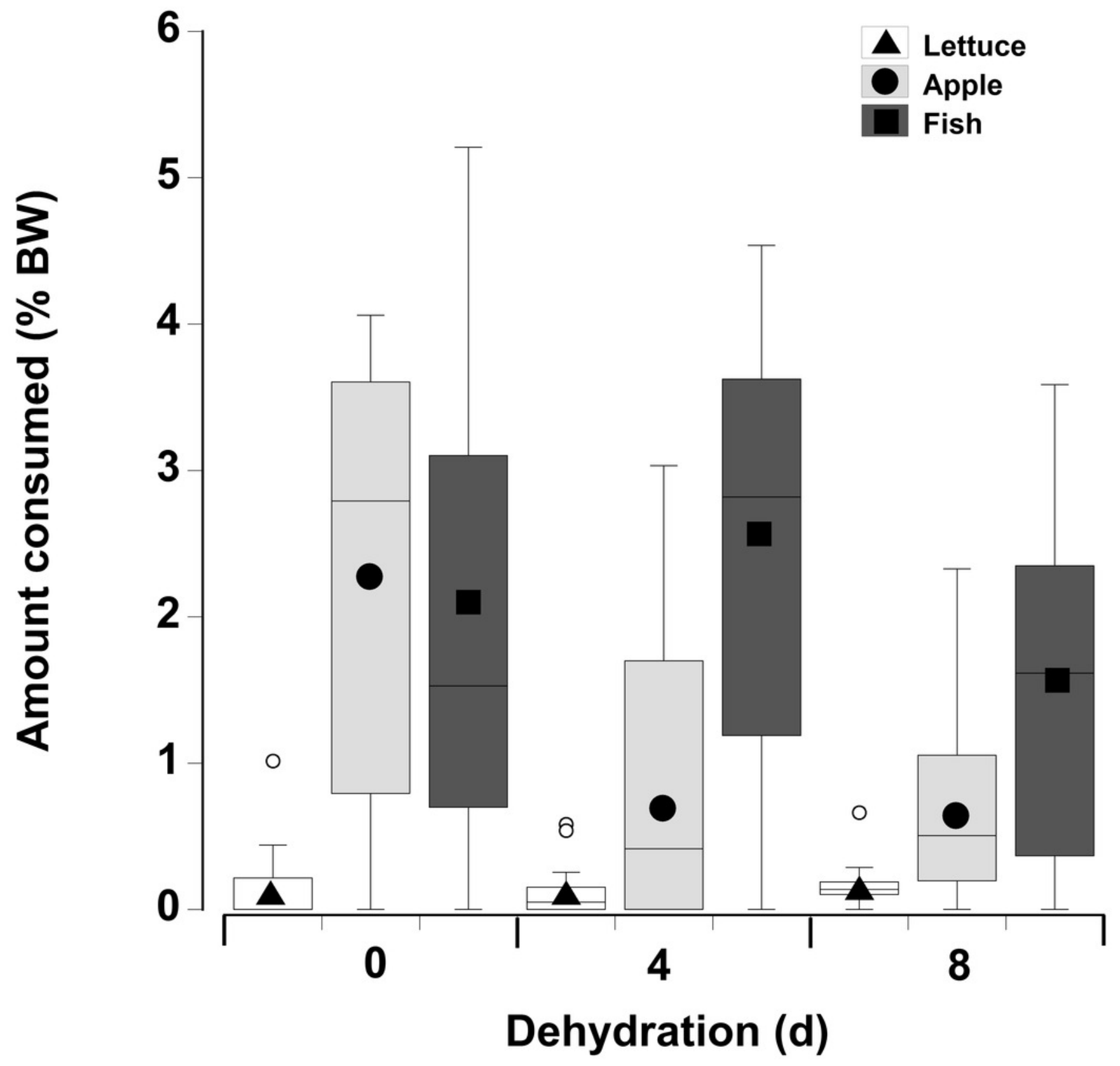




\section{Figure 7}

\section{Effect of crab size on feeding preferences}

Amount of fresh lettuce, apple, or fish consumed (\% dry mass as a function of animal dry mass) of land crabs varying in size between $25 \mathrm{~g}$ and $475 \mathrm{~g}$ when offered a multiple choice of the 3 food items. Each crab was maintained it a separate experimental container and the food items were offered in excess in order to maintain a multiple-choice of food items throughout the $12 \mathrm{~h}$ experimental period. Only fully hydrated crabs were used in this experiment. 


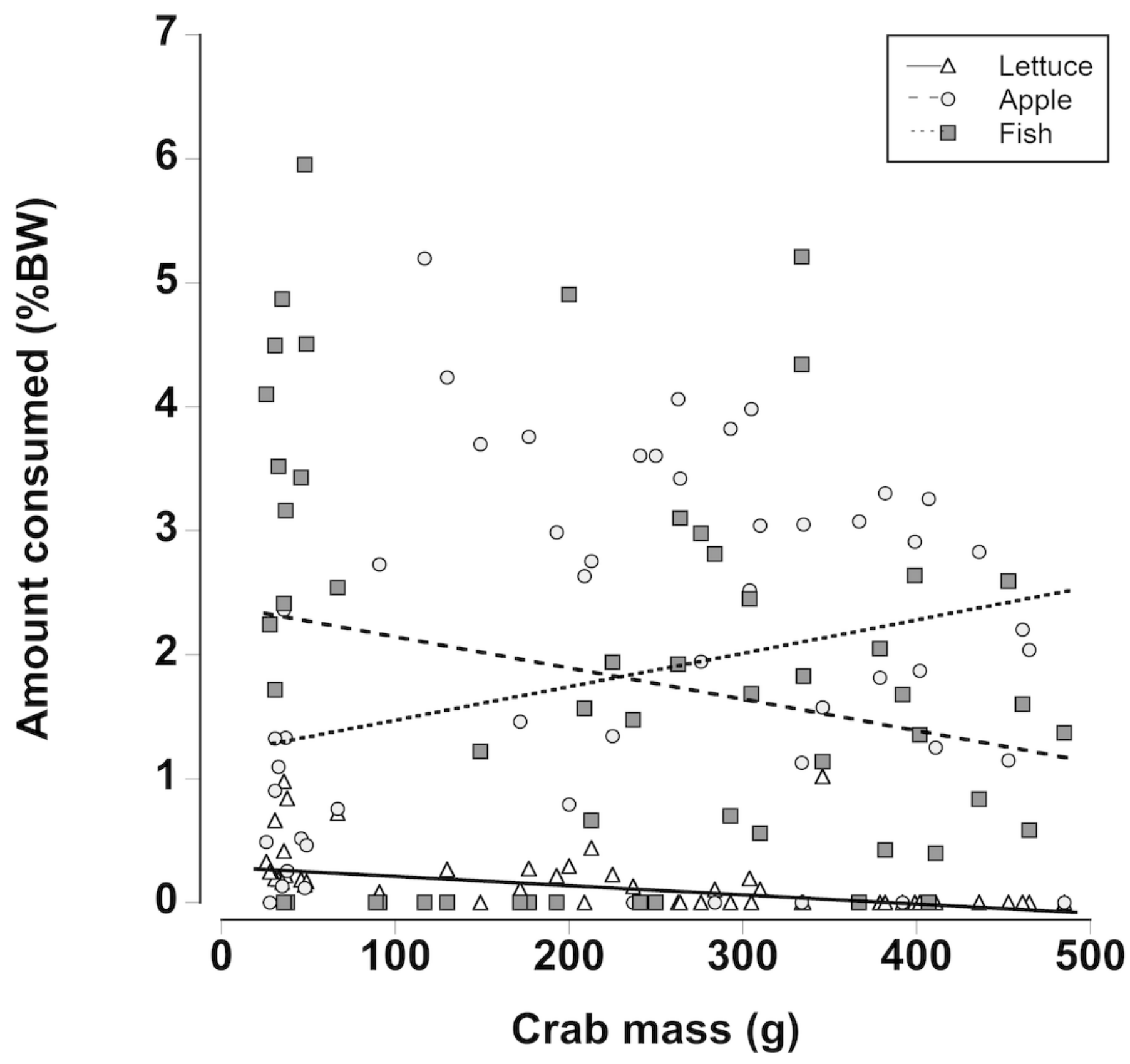




\section{Table $\mathbf{1}$ (on next page)}

Changes in food mass

Regression statistics and equations for changes in mass of the three fresh and dry food types after $12 \mathrm{~h}$ in air at $25+2{ }^{\circ} \mathrm{C}$. These were used to calculate the mass eaten and for converting all masses eaten to a dry mass. 


\section{Table 1}

Item

\# samples $\quad$ Regression statistics

Equation (start=grams)

$\mathbf{R}^{2}$

Fresh lettuce - weight change

Dry lettuce - weight change $\quad 28$

$(\mathrm{F}=8994, \mathrm{P}<0.001)$

final $=-0.499+(0.891 *$ start $)$

0.996

Fresh apple - weight change

$(\mathrm{F}=4121, \mathrm{P}<0.001)$

final $=-0.0127+(1.155 *$ start $)$

0.993

Dry apple - weight change

38

$(\mathrm{F}=12096, \mathrm{P}<0.001)$

final $=-0.110+(0.927 *$ start $)$

0.997

Fresh fish - weight change

31

$(\mathrm{F}=12206, \mathrm{P}<0.001)$

final $=0.144+(1.038 *$ start $)$

0.998

25

$(\mathrm{F}=45089, \mathrm{P}<0.001)$

final $=0.0486+(1.010 *$ start $)$

0.999

Dry fish - weight change

22

$(\mathrm{F}=185751, \mathrm{P}<0.001)$

final $=-0.374+(0.957 *$ start $)$

1.000

Lettuce - water content

24

$(\mathrm{F}=1410, \mathrm{P}<0.001)$

$\operatorname{dry}=0.0508+(0.0530 *$ wet $)$

0.986

Apple - water content

23

$(\mathrm{F}=260, \mathrm{P}<0.001)$

dry $=0.0164+(0.144 *$ wet $)$

0.927

Fish - water content

22

$(\mathrm{F}=1023, \mathrm{P}<0.001)$

dry $=-0.0973+(0.360 *$ wet $)$

0.982

Crab - water content

18

$(\mathrm{F}=744, \mathrm{P}<0.001)$

$\operatorname{dry}=3.622+(0.319 *$ wet $)$

0.976 


\section{Table 2 (on next page)}

\section{Maximal metabolic rate of crabs}

Maximal metabolic rate $\left(\mathrm{mg} \mathrm{O}_{2} \mathrm{~kg} \mathrm{~h}^{-1}\right.$ ) and the scope of the response (maximal metabolic rate/resting metabolic rate) of land crabs following 0,4 and 8 days of dehydration followed by recovery, R after 1 day access to water. The values represent the mean + SEM of 8 animals; different letters denote significant differences at $\mathrm{P}<0.05$. 


\section{Table 2}

\begin{tabular}{|c|c|c|c|c|}
\hline & Od & $4 d$ & $8 d$ & $\mathbf{R}$ \\
\hline $\begin{array}{l}\text { Maximal metabolic rate (MMR) } \\
\left(\mathrm{mg} \mathrm{O}_{2} \mathrm{~kg} \mathrm{~h}^{-1}\right)\end{array}$ & $160.2 \pm 13.5^{\mathrm{ab}}$ & $198.7 \pm 17.5^{b}$ & $155.5 \pm 13.8^{a}$ & $139.5 \pm 12.7^{a}$ \\
\hline Scope & $2.5 \pm 0.2^{\mathrm{a}}$ & $3.2 \pm 0.2^{\mathrm{ab}}$ & $4.6 \pm 0.6^{b}$ & $2.4 \pm 0.2^{\mathrm{a}}$ \\
\hline
\end{tabular}




\section{Table 3 (on next page)}

\section{Statistics for consumption of wet and dry foods}

Food consumption of single fresh and dried food items. The following factors were included in a generalized linear Poisson regression: days dehydration (0,4 and 8), food type (lettuce, apple, and fish), moisture level (fresh, dry) and interactions between: food type*days dehydration, days dehydration*moisture level, and moisture level*food type. The "Intercept" is the reference and represents Day0, Lettuce, Wet - all treatments are contrasted against the reference. $\mathrm{SE}=$ Standard Error, Value $=$ Coefficient Estimate, $\mathrm{ci}=$ Confidence Interval. Residual deviance $=15622$ on 238 degrees of freedom. The data were based on 14 individual crabs for each food type and each dehydration level monitored in separate containers. 


\begin{tabular}{|c|c|c|c|c|c|c|}
\hline Factor & Value & SE & t-value & p-value & $2.5 \%$ ci & $95 \%$ ci \\
\hline Intercept & 4.727 & 0.025 & 191.497 & $<0.001$ & 4.678 & 4.775 \\
\hline Day 4 & -0.380 & 0.038 & -9.967 & $<0.001$ & -0.455 & -0.305 \\
\hline Day 8 & -4.494 & 0.040 & -12.412 & $<0.001$ & -0.573 & -0.417 \\
\hline Apple & 0.726 & 0.030 & 24.403 & $<0.001$ & 0.668 & 0.785 \\
\hline Fish & 0.576 & 0.031 & 18.767 & $<0.001$ & 0.516 & 0.637 \\
\hline Dry & -2.031 & 0.061 & -33.335 & $<0.001$ & -2.153 & -1.914 \\
\hline Day $4 *$ Apple & 0.457 & 0.044 & 10.374 & $<0.001$ & 0.371 & 0.544 \\
\hline Day $8 *$ Apple & 0.467 & 0.046 & 10.119 & $<0.001$ & 0.377 & 0.558 \\
\hline Day $4 *$ Fish & 1.181 & 0.044 & 26.955 & $<0.001$ & 1.095 & 1.267 \\
\hline Day $8 *$ Fish & 0.272 & 0.048 & 5.619 & $<0.001$ & 0.177 & 0.367 \\
\hline Day $4 *$ Dry & -0.738 & 0.044 & -16.655 & $<0.001$ & -0.825 & -0.651 \\
\hline Day $8 *$ Dry & -1.179 & 0.056 & -20.999 & $<0.001$ & -1.290 & -1.070 \\
\hline Apple $*$ Dry & 1.006 & 0.064 & 15.647 & $<0.001$ & 0.882 & 1.134 \\
\hline Fish * Dry & -0.252 & 0.072 & -3.478 & $<0.001$ & -0.393 & -0.109 \\
\hline
\end{tabular}




\section{Table 4(on next page)}

Number of crabs feeding on wet and dry food

Number of animals feeding (total of 14) on fresh or dry lettuce, apple, or fish when offered a single choice of each item as a function of being dehydrated for 0,4 or 8 days. The data represent a total of 14 animals (with 1 animal per experimental container) per food item and different animals were used for each food item and each dehydration level. 
1

2 Table 4

3

4

5

6

7

8

9

10

11

12

13

14

15

16

17

18

19

20

21

22

23

24

25

26

27

28

29

30

31

32

33

Meal

Dry fish

\section{Dehydration (days)}

Od

4d

8d

Fresh lettuce

14

13

11

Dry lettuce

6

5

3

Fresh apple

13

14

13

Dry apple

14

10

7

Fresh fish

12

14

13

9

2 


\section{Table 5 (on next page)}

\section{Multiple choice experiment statistics}

Multiple choice experiment. The following factors were included in a generalized linear Poisson regression: days dehydration ( 0,4 and 8 ) and food type (lettuce, apple, and fish) and interactions between: food type*days dehydration. The "Intercept" is the reference and represents Day 0 , Lettuce - all treatments are contrasted against the reference. $\mathrm{SE}=$ Standard Error, Value $=$ Coefficient Estimate, $\mathrm{ci}=$ Confidence Interval, \%diff = percentage change. Residual deviance $=10697$ on 117 degrees of freedom. The data were based on 14 individual crabs at each dehydration level monitored in separate containers. 


\begin{tabular}{|c|c|c|c|c|c|c|}
\hline Factor & Value & $\mathbf{S E}$ & t-value & p-value & $2.5 \%$ ci & $95 \%$ ci \\
\hline Intercept & 2.698 & 0.069 & 38.919 & $<0.001$ & 2.559 & 2.831 \\
\hline Day 4 & -0.101 & 0.101 & -1.005 & 0.315 & -0.299 & 0.096 \\
\hline Day 8 & 0.092 & 0.096 & 0.957 & 0.338 & -0.096 & 0.280 \\
\hline Apple & 2.700 & 0.072 & 37.690 & $<0.001$ & 2.562 & 2.843 \\
\hline Fish & 2.264 & 0.072 & 36.540 & $<0.001$ & 2.486 & 2.768 \\
\hline Day $4 *$ Apple & -0.844 & 0.106 & -7.950 & $<0.001$ & -1.052 & -0.636 \\
\hline Day $8 *$ Apple & -1.122 & 0.103 & -11.817 & $<0.001$ & -1.413 & -1.011 \\
\hline Day $4 *$ Fish & 0.268 & 0.104 & 2.580 & 0.010 & 0.064 & 0.472 \\
\hline Day $8 *$ Fish & -0.360 & 0.100 & -3.597 & $<0.001$ & -0.556 & -0.164 \\
\hline
\end{tabular}




\section{Table 6(on next page)}

Number of crabs feeding in multiple choice experiment

Number of animals feeding (total of 14) when offered a multiple choice of fresh lettuce, apple, or fish as a function of being dehydrated for 0,4 or 8 days. The data represent a total of 14 (different) crabs, for each dehydration level (each crab was held separately in an experimental chamber). 


\section{Table 6}

10

11

12

13

14

15

16 Lettuce

17

18 Apple

19

20

Fish

12

11

10

12

21

22

23

24

25

26

27

28

29

30

31

32

33

34

35

36

37

38

39

40

41

42

43

44

45 


\section{Table 7 (on next page)}

Statistics for crab size and food choice

Effect of crab size on food preference. An individual crab was held in the experimental chamber and offered the 3 food types. A general least-squares regression included crab body mass and food type (lettuce, apple, and fish), with an interaction term. The "Intercept" is the reference and represents "Lettuce" for crabs with 0 mass - all treatments are contrasted against the reference. A different standard deviation per food type was modelled (using a weights function as described in the methods) with a ratio of Lettuce $=1.000$, Apple $=1.146$, and Fish=0.126. SE $=$ Standard Error, Value $=$ Coefficient Estimate. Degrees of freedom $=$ 162. 


\section{Table 7}

\begin{tabular}{|c|c|c|c|c|}
\hline Factor & Value & SE & t-value & p-value \\
\hline Intercept & 35.206 & 4.447 & 7.917 & $<0.001$ \\
\hline Crab Mass & -0.093 & 0.017 & -5.590 & $<0.001$ \\
\hline Apple & 90.327 & 35.590 & 2.538 & 0.012 \\
\hline Fish & 199.968 & 40.694 & 4.914 & $<0.001$ \\
\hline Crab Mass * Apple & 0.349 & 0.133 & 2.626 & 0.010 \\
\hline Crab Mass * Fish & -0.165 & 0.152 & -1.088 & 0.278 \\
\hline
\end{tabular}

